\title{
5 The University Setting
}

The basic practicum in the Tyrolean elementary schools is an important element of the interreligious collaboration in the education of prospective Catholic and Islamic religion teachers at the University of Innsbruck. There are two parts: the school practicum and the university course. The focus of this chapter are the areas of conflict that arise in the university setting as a result of the interreligious collaboration in the course.

Three different fields of tension manifest themselves in the assessment of the empirical data material:

- Area of conflict 1: Planning, approach, and expectations (chapter 5.2)

- Area of conflict 2: Process, communication, and group dynamics (chapter 5.3)

- Area of conflict 3: Conflict about 'ideal' religious education and recognition (chapter 5.4).

To contextualise these fields of tension sufficiently, the university setting will be described in section 5.1. In that section we will introduce the interests and expectations of the participant groups of the university course and the interreligious approach in the education of the religion teachers.

\subsection{Description of the University Setting}

\section{General Conditions}

Muslim students in the Islamic Religious Education (Bachelor's) programme, do a practicum together with Catholic students in Catholic religious education in Tyrolean elementary schools. These initial insights into the educational context of the school are accompanied by a university course. The students who attend this course come from three study programmes: Islamic Religious Education (Bachelor's programme), Catholic Religious Education (Bachelor's programme) and Catholic Theology (diploma programme $\mathrm{e}^{1}$.

The accompanying course for the basic practicum is compulsory for both Bachelor's programmes. For the prospective religion teachers, attendance and passing the course are required if they want to continue with this programme

1 A diploma degree programme was the standard course of study in Austria (and in Germany) before the introduction of Bachelor's and Master's degree programmes. The diploma programme in Catholic Theology lasts ten semesters. Graduates are qualified to pursue a doctorate.

Ә OpenAccess. (c) $2022 \mathrm{Kraml}$, Sejdini, Bauer, Kolb, published by De Gruyter. (cc))BY-NC-ND This work is licensed under the Creative Commons Attribution-NonCommercial-NoDerivatives 4.0 International License. https://doi.org/10.1515/9783110762877-007 
of study. For students of Catholic Theology, attendance is not compulsory, but they can fulfil the requirement by taking an elective.

Students are constantly assessed during the course, and they are required to attend. In general, the course work is concluded with a written test that includes both documentation and reflections on the school practicum and on the university course work. The assessment of the written work is not graded but is simply pass-fail: 'successfully completed' or 'unsuccessfully completed'. Given the students' individuality, a more precise evaluation of their performance is hardly possible.

The course is given by an interreligious team of two teachers and is offered only in the winter semester. It is not given over the entire semester but in blocks of four to five units, geared to the practicum blocks indicated in the weekly roster in the schools.

\section{Participating Actors in the Context of the University Course}

Various groups play a role in the university setting. On the one hand, there are the university institutes of the University of Innsbruck that offer the programmes and initiated the interreligious collaboration. On the other hand, the instructors who give the course and the participating students who take it play roles as well. These groups and institutes constitute the setting in which the fields of tension at the university setting are embedded or from which conflicts emerge. The participating actors at the university setting are presented in figure 5. 


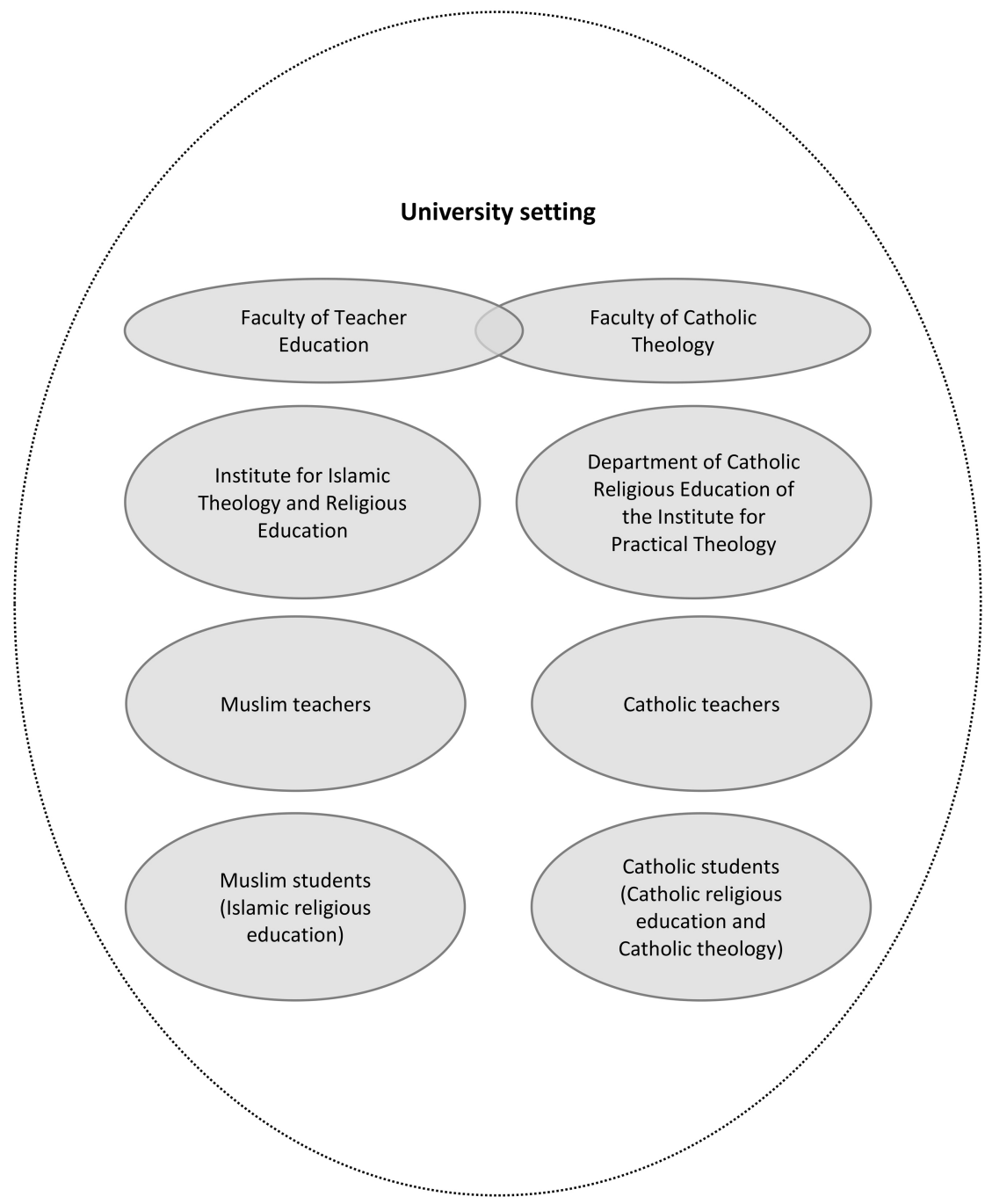

Fig. 5: Participating Actors in the University Setting

The participating actors represent various individually and structurally formed interests, concerns, and perspectives on the events and developments in the university context. In the next section, we will first look at the interests, positions, and expectations of the university institutions (group of actors I) regarding the interreligious setup of the course accompanying the basic practicum. We will 
then turn to the teachers (instructors) (group of actors II) and the students (group of actors III).

\section{Group of Actors I: The University Institutes}

In the university setting, there is on the one hand the Institute for Islamic Theology and Religious Education, which has existed as an independent organisational unit at the university since 2017 and was previously a department in the Institute for Didactics (then still limited to Islamic Religious Education). On the other hand, there is also the Department of Religious Education at the Institute for Practical Theology. Whereas the Institute for Islamic Theology and Religious Education is part of the Faculty of Teacher Education, the Institute for Practical Theology is part of the Faculty of Catholic Theology at the University of Innsbruck. The Professor of Catholic Religious Education, whose field of activity includes the education and training of Catholic religion teachers, is a member of both the Faculty of Catholic Theology and the Faculty of Teacher Education. The interreligious collaboration thus transcends not only particular institutes but also faculties. This cross-over between faculties is represented in figure 5 by the interface between both faculties.

Since Islamic Religious Education was included in the University of Innsbruck as an academic discipline, there has been close collaboration with the Department of Religious Education. Among other things, the three study programmes already mentioned have been offered by both participating faculties. Interreligious collaboration is carried out in various modules in the education of prospective religion teachers, especially in the basic practicum. This collaboration is embedded in the curricula of programmes in religious education.

Whereas the programme of Islamic religious education contained interreligious elements right from the start, these interreligious aspects have been recently introduced in the curriculum of Catholic religious education and the programmes adjusted accordingly. This transformation can be seen in the basic practicum: before this interreligious collaboration, the concomitant course for the practicum was set up only for Christian students. The interreligious collaboration thus entailed a challenge particularly for the teachers of the course to reshape the course accordingly.

With the plan to give an interreligious form to the modules of the programmes, the professors who were involved at the participating universities sought in principle to create and guarantee the long-term existence of the best possible programme for prospective religious teachers. This decision was made with a long-term perspective and with the conviction 'that, given the social changes occurring, the future of religious education lies in interreligious collab- 
oration.'2 In the view of those setting up these programmes, the prospective teachers had to undergo interreligious experiences in their own education if they were to be able, as religion teachers, to deal adequately with religion in a pluralistic society in general and with religious diversity in schools in particular. Moreover, it was desired that, through their encounter with the religious other, Catholic and Islamic religion teachers would also look beyond the religious didactic norms of their own religion. The professors involved here on behalf of the departments of religious education of the participating university institutions thus see religious difference as potential that can also be used constructively in the university education of religion teachers. ${ }^{3}$ They saw interreligious collaboration and the resulting broadening of the perspectives of the students as positive and as promoting the quality of the programmes. Because becoming familiar with the school as a place of learning and the setting of education is required for both Catholic and Muslim religion teachers, the decision was made that they would work together in an interreligious way in these components of their education and to give them jointly.

\section{Group of Actors II: The Course Instructors}

The course instructors ${ }^{4}$ take on the role of educating the prospective Catholic and Islamic religion teachers. They strive to make a positive contribution to the university education of these teachers and to pass on important competences and abilities to them. In their position as teachers of the course, they are, moreover, to assess the progress of the prospective religion teachers during the course that accompanies the basic practicum.

The concern of the instructors consists primarily in implementing the learning objectives of the course and to stimulate learning processes that will benefit the students. One stated objective is that the students first undergo supervised teaching experiences at a school as a team and as individual teachers. This includes exploring the educational context of the school in general and the concrete teaching event in the form of observation in the school context and in the actual teaching that was done. The role and practice of religion teachers

$2 \mathrm{Kraml}$ / Sejdini, Der Forschungskontext, $14 \mathrm{f}$.

3 Cf. Kraml, Martina / Sejdini, Zekirija, Religiöse Unterschiedlichkeit als Potenzial. Innsbrucker Interreligiöse Religionspädagogik und Religionsdidaktik. In: Österreichisches Religionspädagogisches Forum (2015) 1, 29-37.

4 Here we refer again to the strategy of anonymisation that we have been using. Because the teachers we interviewed were usually women, and male teachers were a minority, we use only female pseudonyms to protect the anonymity of the interviewees. 
are also explored. Moreover, the course work is directed at reflecting on and processing one's impressions of observing teaching and the first experience of teaching independently. Beyond this, the course teachers attempt to provide an introduction to the systematic planning of instruction processes.

In many cases, the accompanying course is not the only course that the teachers give. This can lead to thematic or methodological references to other courses or fields emerging in the interviews or in the participants introducing these references into the course itself.

To be able to teach the course, a professional qualification in religious education or didactics and competences in higher education didactics are crucial. It is not required that one be a religion teacher, but it is an advantage. Most teachers who give the course that accompanies the basic practicum, however, were or are religion teachers.

The praxis in the university course and the experience in teaching at the elementary school are influenced differently by each instructor. Differences between the Muslim and the Catholic instructors that result from the history of the course become manifest here. It can be clearly seen that Islamic Religious Education is a new discipline and that the corresponding programme at the University of Innsbruck has existed for only a few years. While the Catholic instructors have often been teaching for a long time, the Muslim instructors usually have less experience in teaching.

Because of the different initial conditions, the Islamic and Catholic teachers are confronted with different challenges. While the latter do have more practical experience in the implementation of the course accompanying the basic practicum, they were nonetheless entrusted with a new task, i.e., turning a course designed for a homogenous Catholic audience into an interreligious one. The interreligious collaboration was unusual for the Catholic instructors. In addition, they were to give the course in a team with someone from another theological discipline, which was still in the process of becoming established. For their part, the Muslim teachers first had to appropriate the content and methods for the course and at the same time adjust to the procedures of team teaching. The interreligious collaboration was a new experience for them as well.

In general, the course accompanying the basic practicum was given by external instructors. These instructors often have no close connection with the participating university organisations and are hardly embedded in the work of the institution. Their external status can represent a problem for those involved, particularly in new developments at an institute or for recording current dynamics. How the status of the external instructors affects the course, however, differs from person to person. 


\section{Group of Actors III: The Students}

In connection with the basic practicum in the school, the students as a rule take on the role of teacher for the first time in an elementary school setting. Until then, they have not usually experienced school life and teaching from this perspective. The students expect the course and their teachers to prepare them for that new role and the accompanying challenges. Corresponding to the description and the learning objectives formulated in the course catalogue, the students moreover assume that the experiences they gain at school will be followed up and reflected upon. They want to be actively supported by the teachers in expanding their competences, skills, and knowledge. Consequently, the students see the seminar and the practicum at the school as a necessary step in the qualified education of prospective teachers.

The content that the students concretely expect and want varies from person to person and from study programme to study programme. The following expectations regarding content in connection with the practicum were gleaned from the interviews:

- Learning and trying out methods

- Understanding didactical information and planning teaching units

- Interreligious exchange

- Encounters with the religious other

- The observation of religious education of another religion.

In some cases, however, the expectations are quite vague. The interreligious component is usually assessed on the basis of experiences in the religious education that occurs in their own religion.

The expectations differ according to age and according to the students' progress in their studies. As already stated above, Muslim students in the period we researched attended the university course at an early point in their education, whereas their fellow Catholic students completed the basic practicum in a later semester of their programme. Given their greater experience in studying, the latter are more proficient at expressing their expectations of the course or participating actively in it. Because of this, a disparity developed between the students from different fields, which can be expressed in the course of the implementation of the units.

The perspective of the students on the practicum and the university course is, aside from the aspects mentioned, fundamentally stamped by the fact that it is a compulsory component of the programme. Muslim students who are enrolled in the Islamic Religious Education programme and their fellow students who are studying Catholic religious education have to complete this component in order to graduate. This also applies to students of Catholic Theology who take 
the basic practicum as an elective. The fact that the course is not graded does not have any demonstrable influence on the students' commitment or attendance. Both are required by the course teachers with no change.

Having presented the perspectives and interests of the participating group of actors that are important in the interreligious collaboration in the university course, in the next section we will look at the various areas of conflict in the university setting that can be identified in our analysis of the empirical data. We will begin with the first area, which has to do with the planning, approach, and expectations.

\subsection{Area of Conflict 1: Planning, Approach, and Expectations}

It is clear from the analysis of the interviews that the approaches, planning proposals, and expectations concerning the course that accompanies the basic practicum often included tensions for the interviewees. We therefore included these themes in the first area of conflict in the university setting. Here the following perspectives are central: those of the course teachers and those of the students as the participants in the university part of the basic practicum. In the analysis and categorisation of the interview results, it should be kept in mind that the participants provide their perspective in retrospect.

\subsubsection{Causes and Influential Factors}

In this section we will look at the structural conditions as causes and influential factors in the conflicts in the university course component of the basic practicum. In reference to the general structural conditions, there is the perspective of power asymmetries in the context of interreligious/intercultural education. These asymmetries represent a central foundation for conflicts.

With their perspectives and concepts, both groups influence in different ways the dynamics of conceptualisation, implementation, and evaluation of the course. Regarding the instructors, one could speak of a direct influence, and with respect to the students, of an indirect, somewhat later emerging, influence. Concerning the general structural conditions, a crucial role is played by whether the course is taught by one person or a team of one Muslim and one Catholic instructor. In this case, it is the challenge of collaboration and the corresponding expectations regarding structure that essentially influence the teaching. Another general influential factor on the part of the course instructors is the fact that both instructors of the course were external instructors and thus not 
very familiar with the routine interreligious work done in the university institutes. The dynamics of a course in relation to the number of students enrolled (size of the group) and its composition are more general in nature, and they can have a strong influence on the course. We will outline our assessment of these and other structural conditions on the part of instructors and students below.

The Muslim instructor Mehtap, for example, holds that that basic practicum is structured too one-sidedly in favour of Catholic religious education. The practicum should not only be done in Catholic religious education but also in Islamic religious education:

It would be perfect ... if the Catholic students were also present at Islamic religious education. And if they ... could sit in, and it would be fantastic if in both blocks the students sit at the back and in each the student of the respective religion tries out teaching sequences and then reflects on them once more in the reflection section in the university part. That would be the best solution. (IP Mehtap, lines 1902-1907)

The theme of power and power asymmetries mentioned at the beginning can be seen here; they can be noticed quite frequently in interreligious education constellations. The Muslim instructor here observes an inequality and criticises the one-sidedness of the settings in which the practicum occurs.

The Catholic instructor Hilde presents a similar point of view. In this context, she takes up an argument that already played a role in the preparation of the programme plan, namely, that the practicum takes place in Catholic religious education: there are so few adequately educated Islamic religion teachers who had completed the mentor training (cf. IP Hilde, lines 2153-2155). Hilde describes the effect of this argument with the words: 'The [Muslims] have not yet got it together' (ibid., line 2156). Here processes and dynamics emerge that concern the formation of stereotypes and advantages with respect to the out-group.

Mehtap, the Muslim teacher, complains that the one-sided Catholic accent of the basic practicum disadvantages the Muslim students in particular. Because of that, they are confronted with themes 'that have no Islamic connection' (IP Mehtap, line 1208). When specifically Christian themes were discussed, the claims represented an almost insurmountable challenge for the Muslim students because they 'do not even know the religious language, the elements of the language of the other' (ibid., lines 1274f.).

Mehtap describes - as do the students - another unfavourable influential factor: the group size and the alternating presence or absence of Muslim students because of another overlapping course. 
To my surprise, I discerned that only a few students were present, Muslim students, and the majority were Catholics. I don't care about that at all, but the number should at least be equal. Thus, that really did disappoint. (Ibid., lines 524-526)

Mehtap goes at length into the 'class conflict' that was the cause of the fact that the Muslim students 'were constantly absent' (ibid., lines 1195f.). The analysis of the interview showed, however, that this was accepted and not discussed by both instructors, nor did they seek to fix it.

Power and power asymmetries were also observed by the students. An example of this is the numerical inequality that above all the Muslim students Esra and Elmas and the Catholic student Sonja mentioned. 'We were simply, Roman Catholics, we were simply in the majority in contrast to the others' (IP Sonja, lines 29-31).

Many students are put off by the course length of four hours and evaluate it as 'strenuous' (IP Meltem, line 45; IP Klara, line 15). Elmas remarks that the course was also more geared to the Catholic students (cf. IP Elmas, lines 139142).

From the perspective of the Catholic teacher Hilde, she and Mehtap were left on their own because they were given few instructions concerning the general conditions. Hilde also noticed different initial conditions for the two instructors. She characterises herself as someone experienced in university teaching and in working with heterogeneous groups. She also has, she says, taught the course several times before, once to a group of Muslim-Catholic students. She portrays Mehtap as someone who is still inexperienced in university teaching. Hilde says Mehtap and she are 'simply at two different points' (IP Hilde, line 1050). Hilde's 'diagnosis' makes clear that she sees the possibilities of being able to communicate or arrive at a common approach as limited because of different preconditions and approaches and does not think that will change.

In the individual and situational conditions, we will first look at the example of the expectations or objectives of teachers and students, as well as their subjective approaches. Of the two instructors, only Hilde speaks explicitly of expectations or objectives. She refers to three aspects. First, she cites as a goal the students understand that they are to 'communicate with each other' (ibid., line 251). She specifies this further as follows:

[T] hey can speak to each other, and they can argue, and they can say to each other: 'That is my point of view, that is your point of view and what can we now do together?' (Ibid., lines 610f.)

As a second concern, Hilde distances herself from a pure learning of methods, which she characterises as 'not expedient and actually as pointless' (ibid., line 
861). A third objective she cites is the acquisition of basic competences, without which it would be impossible, in her view, to act in an educational way: unbiased observation and perception, description, and reflection. In Hilde's opinion, a high-quality reflection phase has two important requirements: first, reflection should occur in the group and, second, it should be done against the background of corresponding approaches (cf. ibid., lines 850-876). That is why Hilde emphasises unbiased observation and conceptual thinking as central:

That is, this reflection, first just this observation, perceiving, speaking about, that is, I think, the basis of, one of the basic bases for teachers, regardless of method. (Ibid., lines 850-853)

Altogether, Hilde's approach to didactics for religion can be seen here. She rejects a 'master-student approach' in which the teacher presents conduct and actions to the student in the form of prescriptions. To her, the challenge lies rather in getting - creatively - from the knowledge made available to one's own professional behaviour.

I presented them with parts of a teaching unit and said, 'With the knowledge, with the view, that you now have, look at it, think about it. What's it mean to you? What would you do differently? For me, something like that also belongs in the basic practicum because it's about developing anew an idea of what it is to be a teacher. (Ibid., lines 862-869)

According to Hilde, this didactic understanding and this way of proceeding is what clearly distinguishes her from her colleague: 'Mehtap just wanted to pass on many methodological and didactic points' (ibid., lines 154f.). Hilde saw these differences in expectations and approaches as a difficulty already before the practicum began, just like her own uncertainty about the interreligious work and tasks of the basic practicum (cf. ibid., lines 1065-1088).

For her part, Mehtap cites, with reference to the structural conditions of the basic practicum, a lack of clarity about the objectives and setup of the course. She is familiar with the concept 'interreligious' from the field of interreligious dialogue, in which she has a great deal of experience. She cannot understand that the goal of an interreligious course should not be interreligious dialogue (cf. IP Mehtap, lines 1665-1669). She had given other practicums in the context of the Islamic teacher education programme and could not discern this as a particular objective in the university part of the basic practicum (cf. ibid., lines 671673).

A second lack of clarity for Mehtap concerns her task as a Muslim instructor and thus her role in the basic practicum: 
Why, on what grounds? And this question ... was not dealt with sufficiently. We knew someone was needed, but why, for what reason? I believe neither Hilde nor I knew beforehand where it should lead. (Ibid., lines 1935-1937)

Another - problematic - side of the basic practicum for Mehtap concerns the implicit messages that, in her view, were communicated by the current approach to the basic practicum. One such message was the view that Islamic religious education was still in need of supplementation. Mehtap states it somewhat ironically:

This is how it goes, this approach tells me in advance, if I view the concept neutrally: 'Look here, people, we Islamic religion teachers cannot teach very well, we will look at the approach used in Catholic religious education.' And that is how they look at it. (Ibid., lines 2269-2272)

Here also, Mehtap experiences the power imbalance we have already addressed several times, which is already manifest on the level of planning and approach. The social group dynamics with its conflict potential also becomes clear through ascriptions that given to the religious other. The approach in the basic practicum in Catholic religious education shows Mehtap that Islamic religious education is viewed as inferior (cf. ibid., lines 2272-2276). The didactic strategy in Catholic religious education is given positive attributes, while the approaches in Islamic religious education are viewed as needing improvement (cf. ibid.). Inspired by the conflict theory of social identity, Mehtap is disturbed by the fact that her in-group is discredited and presented in a negative light.

In contrast to Hilde, for Mehtap, a central concern in the basic practicum is to learn methods, and this also influences her approach to such a course. She grounds this in her view that most Muslim students have only been exposed to the lecture method of teaching:

Students who have been educated in various mosques, they know nothing else than frontal education. And I'm also forced in part to introduce them to other methods so that they say, 'Aha, that Islamic religious education at school differs from mosque education.' (Ibid., lines 2218-2221)

Other than the expectations of the instructors, the students' expectations are mostly imprecise. Most students indicated that they had no concrete expectations or only a few. Esra said: 'I didn't have such big ideas' (IP Esra, lines 155157).

Elmas says that she 'herself didn't know what she needed' (IP Elmas, line 168). A few students - such as Elmas, Emine, Klara, among others - mentioned that what they expected was the construction of a basic stock of methods and 
materials. Via the narratives and descriptions, it becomes clear that the students understand methods as far-reaching instruments independent of conceptions and the individual - in the sense of a set of tools or a kind of 'method case'.

Occasionally, especially among the students of Catholic Theology, the subjective approach to educational and didactical courses becomes evident. They take them less seriously than they do the so-called specialised courses, which marked a point of conflict in studies in Catholic Theology. Max said, for instance, that he was 'not a great friend of educational courses' (IP Max, lines 284f.) and therefore did 'not have many expectations, relatively speaking' (ibid., line 284) in the course.

But altogether, the students think that they benefited from the course in the way it was conducted. Meltem says: 'The expectations were low, what is presented, that was high and helpful for us' (IP Meltem, lines 246-248). Klara also expresses herself in a similar way: 'I learned some things that I used later in my class' (IP Klara, lines 145f.). Klaus and Max, who were critical at first of educational-didactical practical courses, do say that they are mildly pleased. The statements of the Muslim students especially vary as to whether the methods that are used in Catholic religious education could also be used in Islamic religious education. Elmas says that she occasionally had the impression that 'No, so this method can't be used at all' (IP Elmas, lines 410f.).

With reference to interreligious elements, various approaches and ideas are articulated by the students. On the one hand, among the Muslim students the notion that the basic practicum was more geared to the Catholic students (cf., e.g., IP Emine, lines 258-261) comes to the fore. In the statements of many students, it is clear that the unequal general conditions created unequal behaviour. Esra says, 'I believe that the Catholic students in this seminar have a great deal more than me' (IP Esra, lines 155-157). She bases her view on the fact that the Catholic students - because of their stronger presence - had more time for small group work than the Muslim students (ibid., lines 158f.).

For many Muslim students, the course triggered reflections on identity in the sense of specific Catholic or Muslim identity. Thus, criticism is expressed of the too one-sidedly Catholic setup of the university course; its results are viewed as ambivalent; and a more interreligious setup - in any case in part - is preferred or required. While the ideas of what it is to be Catholic are very clear, the criteria for these ascriptions remain uncertain (cf., for example, IP Elmas, lines 139-146). Esra thinks: 'For example, we walked the stations of the cross. That was rather Catholic' (IP Esra, lines 76f.).

At the same time, however, they talk about the chances and opportunities offered by the interreligious approach: 
You also learn things from a different point of view. You then have a different perspective.... And you learn a great deal about ... what others think about certain themes and what others think about Islam. (Ibid., lines 229-232)

Elmas reflects on the perspective from which the analyses of methods are carried out. She states that the question whether most methods are appropriate for Islamic religious education is discussed from the viewpoint of Catholic religious education (cf. IP Elmas, lines 222f.). According to Elmas, the choice of themes plays a decisive role in successful interreligious learning. She cites as a positive example the theme of 'creation', 'where both teachers somehow presented it from both sides' (ibid., lines 55f.). According to Elmas, methods and content influence each other (cf. ibid., line 143). Using this premise, she compares religious didactical approaches in Islam and Christianity and comes to the following conclusion: 'With us, it is always based on principles, and then it's always stricter because it is now compared to that of the other' (ibid., lines 223-225). These principles regarding content are revealed in several examples, according to Elmas. Thus, she believes that 'song holds centre stage in Catholic education' (ibid., line 211) and 'that you are somehow looser, you somehow paint and write poems without content' (ibid., lines $476 \mathrm{f}$.).

Meltem emphasises in particular the possibility for independent learning in the course: 'And then we have gained more understanding if we ourselves are active than if we sit down and listen' (IP Meltem, lines 68-71). Klara sees a peculiarity in the religious character of the basic practicum. She evaluates the course on the basis of the 'interreligious staff' as 'very exciting and very interesting' (IP Klara, line 14). She finds being together and processing themes together is enriching 'as they can occur in Islam instruction or in Catholic religious instruction' (ibid., lines 287-289).

From Klaus' perspective, the interreligious part of the course did 'not really emerge' (IP Klaus, line 100), nor was the dialogue 'really present' (ibid., line 101). The exchange also dealt more with didactical questions than ones of theological content (cf. ibid., lines 117-120). In his view, there was not much interreligious exchange. Interreligious aspects could certainly be seen in the reflection on selected Islamic or Catholic elements and in getting to know and discussing various methods and materials of the religious education of the other. Klaus does wonder what connections the other elements have for his own educational practice or how they can be made fruitful for it: 'Yes, this prayer is actually planned for Islamic education. Can it also be used for Catholic education?' (IP Klaus, lines $54-56)$.

Klaus also sees other interreligious aspects in the compilation of the group (cf. ibid., lines 114-133). Max, whose didactical approach is one of separating 
content and method, does not expect any analysis of content in the course but evaluates it as a 'course on tools' (IP Max, line 533) and adds: 'you don't argue purely methodologically' (ibid., lines 547f.). In reference to interreligiosity, Max emphasises that there 'were few elements where that was truly concretely present' (ibid., lines 226f.), but the interreligiosity of the course could be 'used more intensely' (ibid., line 374).

Sonja, whose demands were quite high because of her activity till then in youth work, says that the new methods did not materialise in the way she wanted, and she had learned 'almost nothing new' (IP Sonja, line 25) beyond the syllabus and the orientation to competences. For example, she wanted more 'input on content' (ibid., lines 339f.). Here she mentions the method of didactic reduction (Elementarisierung).

\subsubsection{Behaviour and Interactions}

In this section we will look at the behaviour and interactions of the students and the course teachers with respect to conceptualisation and expectations. One field of tension for the Muslim students arises from the transferability of methods and content from Catholic religious education to Islamic religious education and thus from the interreligious basic practicum to the Islamic specialised practicum. The opinions of those interviewed differ on the question of how extensive the similarities between both types of religious education are. Their conduct in the group and towards the teachers is influenced by their answer to this question.

Emine, for example, goes along with the interreligious learning of methods and opines:

Thus, I was very happy with it because we were a mixed group, together with Christians, and we learned a great deal; how, for example, in the practicum - how one should start. How and what methods we will use. (IP Emine, lines 15-18)

Emine believes that content can be adapted and is thus relevant for Islamic religious education: 'Yeah, the Christian methods in education, those can be accepted. Because ... some things can be used in Islam' (ibid., lines 523-526). She relates that she took from the university courses what she could use in the religious education in school (cf. ibid., lines 633-639):

For example, everyone says what he wants from God and also says what he wants for his neighbours and partners.... And I can use that in Islamic education. (Ibid., lines 541-554) 
Esra is sceptical, however, that she learned methods of Catholic education in the basic practicum.

In my opinion, it makes no sense to learn Catholic methods. That's why I ask myself again and again. Why I can't explain, but it seems to me illogical because in the practicum I myself, uh, held classes with Catholic pupils. Because we had made everything possible with team teaching. That's why I found it pointless to make it mixed. (IP Esra, lines 93-102)

She thinks that the confrontation with methods of Catholic religious education had little to offer Islamic religious education (cf. ibid., lines $287 \mathrm{f}$.).

For Catholic students, the focus is less on adopting methods than on the question of the allocation of tasks in the team teaching of the course instructors. Sonja perceived a clear distribution of tasks between the two teachers. Questions about the seminar method were not always discussed jointly, such as the question of the absence of the Muslim students:

Yes, it was answered in this way, that Hilde believed that 'Yeah, Mehtap is responsible for that, so she has to account for that with her students, thus the Muslim students, and that she manages it, that's the way it is.' (IP Sonja, lines 652-654)

With respect to interreligiosity, Sonja would like less separation and more joint action, 'more exchange' (ibid., lines 339f.) between Muslim and Catholic teachers and students. She sees the intermittent division into intrareligious groups as difficult for interreligious gatherings:

So, there was no togetherness: 'Let's have a look at their curriculum, let's have a look at our curriculum.' Or so. But we were really separated again.' (Ibid., lines 71-73)

A differentiated image emerges on the part of the course teachers as well with respect to behaviour and interactions. Since only a few Muslim students attended the course and the others were absent because of an overlap with another course given at the same time, Mehtap sees herself marginalised by both the circumstances and the themes:

I don't get through [to all students] and what's left for me? In a group where Muslims are in the minority and because of a time conflict only a few are present: If I asserted myself, then I would be in a situation then I would talk to students and ... the Muslim students were not even there. (IP Mehtap, lines 1682-1686)

Mehtap relates that she has resigned herself to this situation (cf. ibid., line 1748). To plan the course, however, she needs information about the group beforehand and a reflection on the course. 
I always have to imagine what the class situation will be like, then I can form an image of it. I need that. And I always need to reflect with Hilde at the end of these four afternoons. (Ibid., lines 702-705)

She also needs concrete content. Apparently, she misses this in the conception of the basic practicum: 'I need this "what".... There must be content in which I can find myself again as a person, what I can agree with' (ibid., lines 1402-1404).

Hilde refers to the fact that, she 'attempted a mixture in a completely pragmatic way' (IP Hilde, lines 155f.) together with Mehtap. From her perspective, the pragmatic mixture was not only advantageous but also stood in the way of the structure and content of the basic practicum: 'And after the course this mixture brought us again and again to the point that it was not clear what the basic practicum should really be' (ibid., lines $156 \mathrm{f}$.).

To be able to reach a consensus, Hilde distances herself from her original ideas and tries a more methodical orientation for the course (cf. ibid., lines 1086-1088). Mehtap also relates that she withdrew when confronted with Hilde's approaches and interactions. For Hilde, consideration for the other teacher defined the team teaching. Based on her experience, she attempted initially to give room to Mehtap. Because the course consequently developed in a direction Hilde did not want, she decided later, however, to take over the supervision of the course. Even in the choice of methods, Hilde made sure to avoid content that could stand in the way of the group's togetherness. For example, she mentioned the blessing, which she - for the sake of this togetherness - replaced by 'best wishes' because she wanted 'to be neutral' (ibid., lines 384f.).

Hilde relates that in an interreligious setting she became rattled again and again. She traced this back to deficient clarifications regarding the basic practicum. She wonders: 'What could be our role at all within that?' (ibid., lines $447 \mathrm{f}$.). As an example of another communication pattern, which not seldom occurs in team teaching settings, Hilde refers to a person acting occasionally in opposition to others - out of the need to create a counterbalance - because this person communicates too self-consciously. Apparently, this communication pattern also occurred in Hilde and Mehtap's interreligious setting.

It often happens indeed if two people lead together and someone gives clear answers that the other person takes such a strong counter-position and either begins to dig in or becomes less rigid. (Ibid., lines 1299-1301) 


\subsubsection{Consequences}

With a view to the first area of conflict, 'planning, approach, and expectations', we should now ask: What consequences do the interviewees draw for themselves? It became clear in the analysis that these consequences are closely bound up with the subjective approach of the basic practicum. In Mehtap's case, this is visible in, for example, the proposals for change. She would like a course in which methods are taught, tested, and reflected upon as well as processed with respect to content. She moors the theological aspect predominantly to the content. According to her, the accompanying university course is

not entertainment but something concrete.... And what they [the students] could also almost translate one-for-one. And they can then come in after and say: ... 'They have explained this method to us, which we also tried out, but we noticed these disadvantages.' ... That's how I imagined the university part. That they get impulses ... various methods if I now think only in terms of Islam and that they are in conversation with me as well, and that I also have a part, an area where they can reflect on the role of a practicum supervisor. That is how I imagine the university part. (IP Mehtap, lines 1845-1854)

Mehtap's description of Hilde's approach, which she associates with 'entertainment' and to which she opposes her own 'concreteness' makes the lines of conflict clear in the sense of an asymmetrical assessment. As the basis for the reflection on method, Mehtap initially proposes a content analysis, from which the methods would emerge. Mehtap sees the theological aspects as very much anchored in this way of proceeding: 'This would truly be an indicator for me, a theological approach' (ibid., lines 1917f.).

With respect to the shape of the course, Mehtap would rather begin with reflection on the praxis:

I would have nothing against scheduling half a period for reflection at the beginning of the basic practicum. Thus, that the students simply reflect on what they experienced in the practicum, that they trade experiences with each other. That is what ought to have happened in the university part. (Ibid., lines 1577-1580)

Regarding the interreligious character of the course, Mehtap also prefers a different approach as well. She wants to orient this more to working on theological themes, such as scriptural texts. In what follows she sketches how she imagines what a religion lesson would look like:

If interreligious dialogue is to occur, that we get content from the Old Testament, then I get content from the Qur'an, that we present briefly for five or ten minutes and leave it to the stu- 
dents, and they should plan a joint lesson or plan methods for development or a phase of deepening or a reflection or a beginning. (Ibid., lines 1665-1669)

It is clear from this passage that Mehtap sees two aspects as central to the conceptualisation of the basic practicum: work on texts and reflection on the practicum experiences of the students.

Hilde's approach to the basic practicum is more strongly moored to meta-reflection and - concerning interreligiosity - interaction. According to her, the focus of the basic practicum lies on 'coming into contact with each other'. Moreover, she sees the practicum as a process-oriented possibility of risking relatively independent first steps in the school context and less as a precursor of the specialised practicum. Against this background, various differences from Mehtap's view emerge, which is essentially oriented to content. Hilde draws the conclusion - in the sense of a solution to these dilemmas - that the situation can best be resolved 'pragmatically' (IP Hilde, line 156). The planning of the accompanying course was done with a great deal of mutual attentiveness and perception (cf. ibid., lines 152-157, 490-497). In her opinion, however, 'everything simply changes completely' (ibid., lines 130-135) if one teacher is absent because of sickness.

Hilde relates that Mehtap raises questions about her role and responsibility in the basic practicum. She herself is less occupied with these topics (cf. ibid., lines 452-467). Against this backdrop, Hilde would like clarity, primarily about the learning objectives. These are not only related to the course but also to the interreligious work in the course. In her view, what was important is ' $a$ confrontation in a large group: what is the objective of mixed interreligious groups and a mixed interreligious teaching team?' (ibid., lines 2056-2058).

Hilde is convinced that a true confrontation with the different positions of the course teachers is necessary prior to the course. According to her, both teachers

agreed to this mixing. And all such mixtures are not meat and not fish, do not have any hands or feet, and I think that we, we have also spoken [in the interview] about having struggled so little with each other beforehand as to what our task is in a mixed interreligious basic practicum. (Ibid., lines 172-176)

Hilde relates that the effect of the different approaches to the basic practicum is like 'throwing a spanner into the works' (ibid., line 962). She concedes that it 'was incredibly exhausting for Mehtap to work with me as well' (ibid., line 1054).

In turn, the students assessed the course as follows: Esra describes the intrareligious part of the course as profitable, whereas she viewed the interreligious 
phases as problematic (cf. IP Esra, lines 130-133). Elmas has a similar view. Based on her approaches and perspective, the intrareligious specialised practicum was 'much more informative and useful than the basic practicum' (IP Elmas, line 802).

Emine turns out to be able to adapt some of the methods used in Catholic religious education and holds: 'Many songs and so we can also use them' (IP Emine, line 101). Aspects of other elements, according to Emine, must be adapted or changed (cf. ibid., lines 534-539).

Meltem provides another assessment. According to her, the course can only be accessed via the praxis in the school and be understood only against this background (cf. IP Meltem, lines 23f.). In contrast to other colleagues, Meltem views the division of themes as balanced:

There were no themes, where more weight was given to Islamic themes or Catholic themes. There were themes for both religions there. Appropriate themes, completely plain themes. (Ibid., lines 832-835)

The students give different answers to the question of how they perceived the interreligious character of the course. Klara links up with the concept of interreligious dialogue. She criticises the fact that the group and circumstances led to the Catholic and Islamic parts not being equally present. But that is precisely what interreligious dialogue would suggest (cf. IP Klara, lines $33 \mathrm{f}$.).

Klaus also expresses the wish for more dialogue in the course units, also independent of the instructors (cf. IP Klaus, line 712). For him, 'interreligious or something of that sensibility' (ibid., line 744) has become important. He views an interreligious supervision team to be a major opportunity because it gives the possibility of splitting the group when a theme concerns only one religion or faith (cf. ibid., lines 448-451).

Max did not perceive any tensions between the students in the course. In his view, the potential of the interreligious group had not been exhausted. He recommends that the teachers in the course teach targeted religiously mixed small groups. If they had done so they would then have been better able to carry out the supervision (cf. IP Max, lines 166-175).

Sonja judges in retrospect that the course teachers taught alongside each other rather than in conjunction with each other. In her view, there were few agreements and understandings on common grounds (cf. IP Sonja, lines 67-73). For example, she brings up how they greeted the students: the Muslim instructor 'greeted everybody one after the other with a handshake' (ibid., line 703), while the Catholic teacher 'stood in front and said "Hello"' (ibid., line 
713). Sonja saw the division into preparation and supplementation as an approach by their teachers:

Thus, one simply prepared the theme and the other always interposed something in the meantime or simply supplemented whatever still seemed to her to be appropriate. (Ibid., lines 671674)

She expresses the wish for much more thoroughly mixed groups that are guided by the course instructors, so that 'simply more emerges, i.e., a co-existence' (ibid., lines $327 \mathrm{f}$.).

\subsubsection{Preliminary Conclusion}

In this first preliminary conclusion, we will look at the following questions: What most characterises the course? And what models or approaches do the individual participants endorse regarding the goal and task of the basic practicum? Here we focus especially on the instructors of the course.

The students have different expectations and approaches regarding the meaning of the designation 'interreligious'. Particularly in connection with ideas of what the basic practicum should achieve, differences between the course teachers emerged that had a mirror image effect on the students.

Conflicts between the course teachers became visible and palpable above all in the behaviour of university teaching. Altogether, it is also clear that the teachers could not resolve the conflicts on their own but by focusing on their own respective approaches and assessments became incapable of acting.

The conflict between the teachers was also perceived by the students. For the Muslim students, who were focused on the specialised practicum and the learning of specific Islamic methods, intrareligious learning in the basic practicum was very demanding. For them, the preparation for the specialised practicum and thus the specific character of Islamic religious education or the methods that many Islamic students saw as allegedly specifically 'Islamic' were the focus of their interest. These ideas were furthered by the approach of the Muslim teacher.

Altogether, numerous themes come to the fore in this area of conflict that go beyond the concrete context of the basic practicum. It is clear that the lessons, especially the team teaching, can cause conflicts. In the planning, the course instructors could arrive at a certain degree of agreement. But in their actual teaching a kind of play acting took shape in which the themes of majority society minority society, majority religion - minority religion, in-group - out-group, 
the familiar - the strange, competence - incompetence were negotiated more implicitly than explicitly, and a certain dynamic developed.

All in all, a series of aspects become profiled in and around the course that could be viewed as a reflection of social conditions writ small. Here, Muslims are ascribed the role of an ethical and religious minority. The discrepancies that are felt and the imbalance between the Islamic and Catholic parts of the course also reflected a socially established power imbalance here. These observations lead to the next area of conflict in which the processes and interactions come more strongly into view.

\subsection{Area of Conflict 2: Process, Communication, and Group Dynamics}

In the area of conflict just discussed above, we focused on planning, approaches, and expectations. Now we want to turn our attention in this section to another field of tension. This one is concerned with the processes, the course, the communication, and interaction as well as the group dynamics in the university setting. In the thematic area, 'group dynamics', so-called 'intergroup conflicts' will be examined. At the centre of these conflicts, according to Tajfel and Turner, we find the negotiation of social identities and social status.

In the course of the interviews, it became clear that this area of conflict is a large one. To analyse these group dynamics, we will examine the perspective of the course teachers on the course, the general conditions, their own activities and their team teaching, as well as the perspective of the students on the group, the teachers, the general conditions, and their own interests. There is a complementary and at the same time contradictory/conflictive picture of actions and reactions, interactions, approaches and counter-approaches, and their own perspective as well as the perspective of the other.

\subsubsection{Causes and Influential Factors}

Our presentation of the causes and influential factors begins with the structural conditions from the point of view of the teachers of the accompanying course. As already explained, both teachers in this research period were hardly involved in the university since they were external instructors. In contrast, they were experienced and acknowledged in other professional fields. The Muslim instructor was familiar with interreligious work in schools, whereas the Catholic teacher had little experience in interreligiously oriented education. 
The communications dynamics show distinct patterns. On the one hand, the course instructors communicated with each other and then informed the group either jointly or individually. On the other hand, situations are sketched in the interviews in which the Muslim teacher spoke only to the Muslim students and the Catholic teacher spoke only to the Catholic students. Conversely, the Muslim and/or Catholic students communicated jointly or individually with the Muslim and/or Catholic teacher. Because of that, a communication triangle arose: 'third' persons or groups dropped out of the communication or were not included in the information exchange or in the agreements.

The teachers are not to be seen here as individuals, but they were acting a specific role and were perceived with their own religious affiliation. Regarding the establishment and social recognition of both religious communities, there are great differences and unequal conditions that also influence the interactions and ways of looking at the other. The Catholic Church is essentially established in Austria; it has more members and enjoys - although decreased because of secular development - social recognition. The Islamic religious community is structured differently, has fewer financial means at its disposal and is less recognised in society - sometimes, it is subject to defamation by the majority society. It is especially relevant to take these power relationships into consideration in analysing conflicts and conflict potential. Theoretically, the question of power relationships can be situated in the model of a 'struggle for recognition's that looks at power asymmetries as well as various social positions, particularly those of status. The 'established-outsider paradigm' formulated by Elias and Scotson also presents a helpful criterion for analysis for understanding the dynamics at the bottom of this.

Another structural influential factor, which was raised primarily by students, is constituted by the irregularities we already mentioned regarding the attendance of the Muslim students. Klara holds that the Muslim students were present 'most of the time' (IP Klara, line 190), but they were repeatedly absent. This had a negative effect on the sense of Catholic and Muslim students being together in one group:

But they were simply often not present, which was noticed because the groups, if you spend four hours together, you're expected to grow together somewhat, even if it is only for four units. But there was a group dynamic, and if two or three people always leave and then return an hour and a half later, that is simply noticed. (Ibid., lines 190-196)

5 Cf. Honneth, Kampf um Anerkennung. 
Here Klara regrets that there was little commitment and common ground to be seen because the general conditions favoured a high degree of not binding to one another.

Max perceived unequal treatment of the Muslim students and was critical of this ('Equal rights for all!' [IP Max, line 423]). His starting point was that the Catholic students were not permitted to be absent so often. They, according to Max, had to decide between the courses that were given in the same time slot. The repeated absence of the Muslim students had an effect primarily on the small groups (cf. ibid., lines 391-431). Sonja also describes this situation as burdensome and difficult (cf. IP Sonja, lines 28-31). In-group/out-group dynamics become clear in this context. Thus, the Catholic students felt that an injustice had been done, as the above example shows, not towards individuals but towards the group that they identify with.

An essential factor in the context of the individual and situation related conditions is the definition of and dealing with supervision. Many open questions, problems, and conflicts between the course teachers became manifest, but were not discussed and processed by them. The instructors were not apparently able to take a metaperspective on their own and shared situation and to reflect critically on their own and other approaches.

A conflict around teaching and the understanding of teaching becomes clear. Thus, for Hilde, communication and interaction are central. She characterises the basic practicum as a place where students can become acquainted with each other (cf. IP Hilde, lines 124-127). Communication and asking questions play an essential role for Hilde also with respect to faith. In her eyes, faith has 'something to do with examination' (ibid., line 1173). She articulates this as follows: 'I can't understand it now. Help me understand it. Or help me to comprehend it' (ibid., lines $1174 \mathrm{f}$.). It is also obvious to her 'to call God into question' (ibid., line 2553).

Hilde observes increasing frictions and disagreements in her relationship to Mehtap. Initially, during the preparation, they had ' a very good personal relationship within the framework of work' (ibid., lines 411f.). But this changed after their joint teaching: the relationship between her and Mehtap is now 'no longer that free of tension' (ibid., line 416).

Hilde judges the communication between the students as ambivalent. The Muslim students had found themselves in a kind of 'diaspora situation' (ibid., line 426). According to her, there were also 'two groups ... within this one large seminar group' (ibid., lines 254-256). Hilde relates that tensions between Mehtap and the Catholic students increased, in which neither party felt they were taken seriously by the other (cf. ibid., lines 1091, 1096). 
Various facets of the individual conditions emerge from the statements by the students. On the one hand, we also see the idea here that the university part of the basic practicum should serve learning (new) methods (cf. IP Klaus, lines 371-374). On the other hand, reference is made to interreligious learning, respectful treatment of each other (cf. IP Esra, lines 649-656), a basic attitude of openness (cf. IP Elmas, line 237), and personal preference such as, for instance, teaching in elementary school (IP Emine, lines 698-700).

An important influential factor here is also appraising the attitude to interreligious dialogue. For Meltem, it is imperative in a dialogue to have sound knowledge of one's own religious content:

It is too painful for me, if I simply don't know many things and I have to learn them first so that I can communicate them to the kids sometime. Or communicate the interreligious aspect - thus in the groups of the other students, the Catholic students. (IP Meltem, lines 1164-1168)

Meltem sees potential in this situation for personal development: 'Because people still have to find their own way, how to manage' (ibid., lines 441-443).

For the Catholic students, it was above all the polarisation and block formation between both groups that were structural influential factors on learning conditions. Thus, the borders drawn between Catholic and Muslim students were also spatial. Klaus refers to a block formation in the form of segregated seating arrangements that developed during the course. According to his depiction, the Muslim students sat together in one part of the room and the Catholic students spread themselves over the rest of the room. Thus, in his view, a 'them and us or us and them' (IP Klaus, line 133) formed. Klaus sees the thematisation of the formation of this group as a difficult undertaking because the basic practicum was too short to create a 'common atmosphere' (ibid., line 141). This group formation was not initially intended as such, but it hardened into a dichotomous juxtaposition.

Like Klaus, Max also locates a block formation and adds that he saw the 'clear block formation' (IP Max, line 398) as normal at first, but then he noted that it did not dissipate. Because of that, in his eyes, not much interreligious togetherness occurred (cf. ibid., line 412). Moreover, Max saw the Muslim students as very reserved and 'not very communicative' (ibid., line 412).

Sonja also speaks about the polarisation between Muslim and Catholic students. This became manifest, according to Sonja, in the spatial divison: 'Thus, in principle it was a U-form, with us on the one side as Roman Catholics and on the other side the Muslim students.' (IP Sonja, lines 33-36)

Klara experiences the block formation as inappropriate and describes her search for strategies to overcome it. To try to break down this positioning, she 
took a seat - in a demonstrative way - on the side where the Muslim students were. She has a positive and open attitude towards them, knows them from previous semesters and is 'very happy' (IP Klara, line 90) that she completed the basic practicum together with them. She is also very encouraged to initiate and continue communication and interaction. Here communication with the Muslim students happens mostly in the breaks: 'Again and again a few dialogues arose in the breaks, also with Muslim colleagues' (ibid., lines 18-21).

Klara is interested in Islam and used the opportunity afforded by a religiously mixed group of students in the course to clarify, with the help of the Muslim students, certain questions about Islam: 'Because I then had questions again and again that they answered willingly' (ibid., lines 38f.).

In general, an entire seminar group should be a reference group for the students. Nevertheless, boundaries between Muslim and Catholic students were revealed in the students' accounts that divided them into two groups. The identification of individual students happened in the first instance not via the joint group in the course but via a more or less 'fictitious imaginary we' ${ }^{\text {. }}$ Here, religious adherence becomes an identification marker. The sub-groups that arose could hardly be broken apart, as can be clearly seen from this example. Rather, a dynamic delimitation and exclusion of the religious other arose.

\subsubsection{Behaviour and Interactions}

What is striking is that when Hilde speaks of the other/the others, she uses the term 'students' when she means the interreligious group. She distinguishes between the students by adding the adjective 'Muslim' or 'Catholic': 'And there was no distinction between Muslim students and Catholic students there' (IP Hilde, line 810). Occasionally, Hilde also uses the substantive expression 'Muslim person' or 'Catholic person' (cf. ibid., lines 1335, 2099 or 2020).

In the interaction between the two course teachers, conflicts manifest themselves that were often not dealt with. Mehtap, for instance, felt she was not taken seriously by Hilde but did not discuss this (cf. IP Mehtap, lines 1781-1783, 1391f.). A particularly impressive example became manifested within the framework of the joint planning of a course unit. During this planning, Hilde offered to write up what they agreed and to send it to Mehtap for feedback. When Mehtap received the documents, she saw that there were parts she could not identify with. She did not give any feedback about that but did not use those parts in

6 Cf. Eickelpasch / Rademacher, Identität. 
her teaching (cf. ibid., lines 766-772). According to Mehtap, passages written by Hilde no longer corresponded with what they had agreed. She felt ignored but did not communicate this:

After our meeting, the plan was already written; it was done by her [Hilde], writing it down. I accepted it then because the group was so small ... and because I believe that the Catholic students are also entitled to appropriate supervision where they can ask questions, thus they have the right to talk to an expert. (Ibid., lines 1653-1657)

Hilde, however, was rattled and annoyed that she did not receive any feedback and did not know how she should deal with Mehtap's way of proceeding (cf. IP Hilde, lines 1466-1478).

Another conflict concerning the understanding of teaching, as well dealing with teaching in a practical way became visible elsewhere. Mehtap voices discomfort about the quick or spontaneous taking over the lead in the team teaching of the course and discloses that in principle she cannot manage with the approach:

'Yeah, you can't just take over?' I have a problem with that. I can't agree with that. And I then, after those four afternoons, I understood how that approach works, how it's implemented,... I don't want to be there. (IP Mehtap, lines 1405-1409)

There are major differences between the teachers of the course and their approaches and diverging concepts and - corresponding with that - normative anticipations or expectations. Because of the limited possibilities of and willingness for communication, a series of entanglements in the constellation of expectations of the first and second order (expectations and expectations of expectations) emerges.

Mehtap has this intertwining of expectations in mind when she characterises herself, with respect to the interaction with both her colleague and the students during the course, as an accurate observer: 'You can learn a great deal from someone's body language' (ibid., line 1126). Another important aspect for her is eye contact:

For me, eye contact is extremely important. And I have noticed, while I was teaching, that many did not even look at me, others were very appreciative and asked for my personal opinions, experiences. (Ibid., lines 1131-1133)

For Mehtap, the perceived rejection is exemplified in a Catholic student by whom she felt ignored. She noticed that but did not bring it up. In the interview, however, she devised a number of 'theories' about what could have affected his be- 
haviour. She is very vague about it, saying, 'Perhaps it is something else' (ibid., line 1045) or 'Perhaps he was to finish his sentence now' (ibid., line 1050) or says, 'There could be so many different factors ... that must not concern me personally' (ibid., 1108-1110). After longer reflection, however, Mehtap concludes that the student's disgruntlement affected her. She did not speak to the student, for she considered her possibilities of action to be limited because her personal understanding of the course saw her as being responsible only for the Muslim students and Hilde for the Catholic students (cf. ibid., lines 1163-1225). Starting from this conception, Mehtap sees her speaking to and reprimanding the Catholic student would, in her mind, be an intrusion into Hilde's area of competence. A competitive situation between the two actors becomes clear above all in Mehtap's statements. For her, the question that arises is that of who 'occupies' which field of action. She insinuates that she can understand the students asking Hilde more often for information because the setting required the knowledge a Catholic teacher would have. Here Mehtap anticipates the perspective of a Catholic student:

I would not ask me either ... if I know that I have to prepare the beginning of a lesson on Caritas by next week, I will not ask the Muslim teacher. She will not be informed.... What would I ask her? (Ibid., lines 1263-1266)

Mehtap relates that she withdrew increasingly from taking the lead in teaching. As reasons for this, she says on the one hand that she taught the second unit by herself because Hilde was sick, and she wanted this to be balanced in the third unit. On the other hand, she says that her role was made obsolete by the absences of the Muslim students (cf. ibid., lines 1805-1807). Mehtap reveals that she is unsatisfied with how the course went but does not say this to Hilde. Overall, an image of Mehtap as acting in a passive and inconsistent way emerges.

Hilde, in turn, is uncertain in the interreligious teaching team about what behaviour towards her Muslim partner and towards the Muslim students is at all allowed in Islam. She asks: 'To what extent is it permitted in Islam [to question the existence of God]?' (IP Hilde, line 2560). She attempts to produce an explanation when she asks Mehtap about this and learns that, personally, Mehtap can allow herself to doubt but has reservations about talking about this in religious class (cf. ibid., lines 2588-2590). Hilde can understand this idea to a certain extent because she herself is occasionally confronted by conservative parents who see her teaching as 'not Catholic' (ibid., lines 2599f.). Hilde places her own convictions over against this criticism. She has 'very many supporting arguments that say very clearly - including the curriculum: "That is very Catholic indeed"' (ibid., lines 138-140). 
One of the problems that stands out here for Hilde is her own uncertainty about the purpose of the basic practicum. She talked with Mehtap about this repeatedly 'for quite a long time' (ibid., lines 135f.). Hilde relates that she often had intense conversations with Mehtap in connection with the course so that she was late getting home after every session (cf. ibid., lines $446 \mathrm{f}$.). Hilde criticises Mehtap's teaching style above all for the fact that she - from Hilde's perspective did not treat the students as equals but instructs them (cf. ibid., lines 12251232). In the course of the interview serious difficulties became manifest in the communication between Hilde and Mehtap. According to Hilde, 'they were both careful ... so that it did not lead to conflict' (ibid., line 2441). In Hilde's description, there was

something between the lines. And perhaps it also had something to do with the fact we were not clear about our task, thus our job as teachers of the course together in this mixed setting there. (Ibid., lines 427-433)

Hilde also wonders whether this change in her relationship to Mehtap could have something to do with 'competition' (ibid., line 1206) in the teaching aspect in the course.

Especially with respect to the interaction with the students, it became clear that Mehtap did not feel she was taken seriously - particularly by the Catholic students - as 'an expert' (ibid., line 1115). In turn, Hilde felt obliged to preserve the 'perspective that Mehtap so wonderfully brought in' (ibid., lines 554f.), when she 'withdrew and retreated' (ibid., line 1107). Hilde believes that Mehtap willingly stepped back - she said to her twice: 'I'm happy that you are taking part in teaching this course' (ibid., line 1500). Considerable differences in Hilde's and Mehtap's perceptions become visible here. Moreover, the respective discontent is not articulated in a way that makes processing it possible or inevitable because the course teachers do not talk to each other about their perceptions and wishes.

From the students' perspectives, it becomes clear that the role change (students - interns - assuming the pupil role experimentally) were not easily kept separate from each other and thus the teachers were sometimes also unaware of this role change. For example, Hilde cites a Catholic student who, in the feedback round, declared in a statement expressly directed at Mehtap, that he 'had often felt like an elementary school pupil' (ibid., line 1129). Hilde responded to that by diplomatically answering: 'Thanks for the feedback. We will take it into consideration and discuss it' (ibid., lines 1131f.).

Power imbalances can be seen regarding the activities of both course teachers and those of their chosen strategies. It thus becomes clear that Hilde emphat- 
ically took the more active role and sought conversation more than Mehtap did. Although interpersonal aspects, which can be traced back to the psychological dispositions of the actors and social factors, are to be taken into consideration as well, socio-political power dynamics are also a factor here. These become part of intercultural contexts to the extent that representatives of groups that find themselves in positions of political power also assume positions of power in intercultural educational contexts. Macro-social behaviour is accordingly mirrored in the micro-processes identified here. Altogether, power asymmetry emerges clearly to the extent that - aside from organisational problems - a discourse of domination on approaches, understandings, teaching experience, transparency, the victim role, competence, etc. occurs.

If we look at the interaction and communication between the students, we can state that concrete perspectives and actions mirror the following themes or discourses: majority/minority relationships, domination, competence, familiarity and strangeness, epistemological themes like right-wrong discourses, etc. The space accorded or denied someone to be present with one's own views gains a special importance.

Esra articulates the various perspectives in the discussions between Catholic and Muslim students and clearly stresses how often these were bound up with a fear of being misunderstood. In her view, the cultural differences represented a barrier that required a particularly precise language from the Muslims. She recognised the fear of being misunderstood and the need to justify themselves to many of her Muslim fellow students:

Yeah, they wear headscarves, for example. Quite simple. Most people think we are oppressed. All kind of things. And if a student comes and says: 'Yeah, my mom wanted me to wear a headscarf.' That feels much differently for us than in the interreligious group. (IP Esra, lines 452 - 472)

Likewise, Esra is also concerned with questions of knowledge. She checks herself closely to avoid mistakes or unpleasant situations. 'I rather withdraw ... above all from the students. Before I say anything wrong, I would rather say nothing' (ibid., line 241). Given this background, she also develops a positive relationship with the Muslim teacher. For Esra, Mehtap is more familiar and more competent than Hilde as far as Islamic religious education is concerned: 'Also, if you are in the small group, it was simply better because she [Mehtap] also has more practical experience' (ibid., lines 61f.).

Esra characterises the relationship between the Catholic and the Muslim teacher as 'normal' (ibid., line 493) and unremarkable. With respect to the division of the students, she relates that a block formation could be detected, but 
they worked repeatedly in religiously mixed groups so that 'interaction or rather communication between us ... was already there, yeah' (ibid., line 197). Moreover, Esra reports about discussions on themes in which they exchanged perspectives and thus came to an understanding

because we simply discussed more, but it was not bad. It was ... actually also good. ... It was simply a theme in both Catholicism and Islam. From their point of view and from our point of view: there was no problem. We were certainly able to finish talking. (Ibid., lines 204-211)

Esra sees a difficulty that arises from the Christian character of religious education: the pupils are familiar with Christian content and the Christian way of proceeding. In this context, Esra feels it is difficult to take over the role of Islamic expert. Sometimes, Esra is not prepared above all to answer the questions she is asked and gives an example. During the basic practicum, she was given the task, together with a Catholic student, of explaining the significance of angels in both traditions. One pupil asked for more precise information, but she was unable to give him any answer. She felt it was too much.

For us, yes, there are angels that are responsible for hell. Zebani ... that's what they are called. I also said, 'There are angels who are responsible for hell.' And then he asks, 'But if they are angels, why are they in hell?' (Ibid., lines 750-755)

For Esra, one difficulty in dealing with this question seems to lie in the idea that she has too little knowledge of the background of the Christian tradition to understand the question and to be able to answer it adequately. Here a Catholic student could take a mediating role. All in all, the examples portrayed show dynamics that make clear that interreligious team teaching is challenging.

Another Muslim student, Elmas, often thematised the role of the Muslim teacher and the interaction of the students. She places the numerically small Muslim student group in relation to the role of the Muslim teacher and therefore sees her possibilities to influence the course as limited or placed in question.

Mehtap could not intervene because there were only the four of us. I mean the others were only Catholic students.... The questions came much more out of this direction (IP Elmas, lines 139-141)

From Elmas' point of view, the Muslim course teacher was not properly able to fit in with the interreligious course setting 'even though she is a very open person' (ibid., lines 145f.). Although Elmas is of the view that the teachers 'had a good agreement before then' (ibid., line 530), she emphasises that Hilde stood 'more at the centre' (ibid., lines $530 \mathrm{f}$.). In reference to the inclusion of the Muslim 
students, Elmas relates that working together 'actually worked well' (ibid., line 245). From her point of view, one characteristic had a limiting effect:

Now that's simply how it is for us. We do not intervene, unless ... if we must, then we intervene and if not, that will do. But they were also like that, I believe, that was not so only from our side. (Ibid., lines 245-248)

Elmas did not observe any serious conflicts between the Muslim and Catholic students. She herself held that the uneven proportions in the discussions had levelled out, and she avoided becoming involved in the education activities. Here as well the dynamics, which we detected more often, that rest on structural inequalities are clear. The internalisation of power relationships become evident through Elmas' passivity and conflict avoidance strategies.

Elmas' fellow student Emine discusses the relation between the students and the course teachers and characterises this relationship as friendly: 'as a relationship of friends, thus not as teacher and pupil' (IP Emine, lines $446 \mathrm{f}$.). Aside from the practicum group, she had contact with the Catholic students only within the group. She preferred to get together with her fellow Muslim students during the breaks (cf. ibid., lines 218-228). Both groups profited from each other with respect to both content and didactics:

So we have learned much from them, they have also learned from us. It was good to be together.... For example, they knew little about Islam. They know more now. And we have learned how they, in the classes, what they all do. (Ibid., lines 179-184)

The Muslim student Meltem emphasises the balanced and relaxed atmosphere that she observed in the course. The interreligious phases gave her confidence:

If questions arose where one never dares to ask them, then you could ask Mehtap. Because it is also a group where you say, 'Okay, there I feel a bit better.' (IP Meltem, lines 804-810)

From her point of view, the course teachers got along with each other 'very, very, very well' (ibid., lines $846 \mathrm{f}$.). They led different parts by turns and were expected 'in any case to continue in the same way' (ibid., line 854). Here, Meltem wishes that the teachers 'approach [the students] in quotation marks' (ibid., lines $856 \mathrm{f}$.). She proposes that they

discuss, speak with the students, to show an interest in them, go to them and say: 'So, do you have any questions? What do you envision about that? What do you think should have been conveyed?' Talk more with the students. (Ibid., lines 859-864).

Klara indicates initially that no serious conflicts arose in the course: 
Thus, there were no major difficulties that became a topic for the whole group, and the minor difficulties - naturally, I can't observe all of them. (IP Klara, lines 224-227)

Regarding the interaction between students, Klara talks primarily about the interaction with the Muslim students. In her opinion, the course offered numerous opportunities to 'ask each other questions' (ibid., line 42). She could talk to the Muslim students about 'issues' that 'people do not usually talk about' (ibid., line 45).

But Klara also detects a fear here as well of asking 'dumb questions' (ibid., line 47). She relates that initially there was 'fear of contact' (ibid., line 180) between the Muslim and Catholic students in the course. She does not, however, see religious affiliation as the reason for this reticence, 'that's also the case if a group meets in the course that has already dome something together and then there are new people there' (ibid., lines 181-183).

During the course, however, the atmosphere 'loosened up' (ibid., line 186), and an 'exchange' (ibid., line 186) developed among the students. According to Klara's descriptions, the Muslim course teacher said - allegedly primarily when she taught alone - repeatedly that she lacked competence in the area of specific Christian themes. Klara did not consider that problematic, however, because, in these cases, the Catholic students could answer the questions asked by the Muslim students (cf. ibid., lines 155-159). Klara experienced the course teacher as 'very open' (ibid., line 142). She emphasises that it is better for people to talk to each other if there are questions or problems. That is why she did not hesitate to let them know if she 'was not happy with something' (ibid., line 144).

In reference to the relation between students and teachers, Klara speaks of good interaction. She did not observe a 'typical' case - 'the professor high above and the student somewhere below' (ibid., lines 236-238). From her perspective, the teachers and students had a much closer relationship, expressed in the German word Miteinander (togetherness) (ibid., line 240). This close Miteinander was also promoted by the invitation made by the teachers to be addressed by the students as $d u$ (the familiar form of address) (cf. ibid., lines 240-245).

Following Turner and Tajfel's theoretical approach to social identity, we see in-group and out-group dynamics that can be described as the fusion of in-group and out-group constructions between teachers and students into a common 'we' (see chapter 2.1). This also has a positive effect on the relation of the students among each other and on the group cohesion. Through common goals, interests, and interactions within the framework of the course, the existing (religious) group boundaries and identification patterns break down.

Altogether, Klara judges the atmosphere in the course to be 'good' (ibid., line 242). There was a problem, however, in her practicum group once that the teach- 
ers could have helped solve. She did not provide any additional details on this incident.

The Catholic student Klaus thinks that Mehtap identifies primarily with the Muslim students. With respect to this, he remarks critically that Mehtap busied herself one-sidedly with the Muslim students; 'So, yeah, we belong together anyway, yeah, a little bit like this' (IP Klaus, line 189). Klaus has the impression that Mehtap saw herself as being 'on an equal level' (ibid., line 194) with the Muslim students and 'we the Catholics' (ibid., line 196) 'simply tagged along', with less attention being paid to them. He also noticed relationship problems between the Muslim teacher and the Catholic students and felt resistance on her part. In his view, Mehtap was not 'not open' (ibid., line 658) to them, which became clear to him, for example, in the conversation about the Christian-Catholic rite of lighting candles:

And for her that was, yeah, actually all she knows about Catholics is [lighting candles] and is not really interested in what else we have to say. (Ibid., lines 212-214)

For Klaus, the problem consists not only in Mehtap's rigid position but also in the fact that she did not take the expertise of the Catholic students seriously. He does not think it is appropriate for Mehtap as a Muslim teacher, to speak about a Catholic ritual solely from an external perspective. He claims that only he and his own group can speak authentically about what is part of his religion (cf. ibid., lines 204-216). ${ }^{7}$

Max also speaks about this theme and states that Mehtap had no regard for the knowledge of the Catholic students about the advent wreath celebration. She explained to the Catholic students how the advent wreath celebration was organised and was confronted with alternative ideas that she, according to Max, did not accept. Max interprets her behaviour as arrogant: 'it is just as she says, that's the only correct way' (IP Max, lines $87 \mathrm{f}$.). He questions the competence of the Muslim teacher:

And it is just then that I think, 'Then don't ask us or research it differently beforehand.' But then to just to present it and say, 'I know it, and that's how it is and must be' is difficult, simply when it's a question of things that have to do with her religion indirectly. (Ibid., lines 87-92).

7 A similar field of tension concerning competence and teaching authorisation occurred in the school setting in the area of conflict 'identity and confessionality' (cf. chapter 4.4). 
Max considers this incident to be the starting point of a visible conflict between the Muslim teacher and the Catholic students. In the wake of the incident presented above, there were differences of opinion between Mehtap and the Catholic students, especially Max and Klaus. Thereupon both wrote an email to Hilde. When Klaus speaks of this incident in the interview, he appears uncertain or ashamed. Also, the unstated purpose of the email was to go around Mehtap and, during the still unresolved conflict, to inform Hilde or possibly to win her for their own side.

Yeah, the two of us then - it was above all in the class where she had taught alone the whole afternoon - thereupon we wrote Hilde an email and told her what happened. Yeah, but then it settled down a bit. So then, then it was only one additional unit, I believe, and we did indeed say, 'Yeah, we, we will talk it about once in the group' or so, but somehow .... So she [Hilde] did not write back and said: 'We'd better discuss it then in the next class.' And anyhow it settled down and the seminar was then done and, yeah. (IP Klaus, lines 223-236).

Klaus observes Mehtap's reaction and notes that in the next unit, which Hilde led completely alone, Mehtap came late and was present only 'marginally' (ibid., line 328), 'more as a listener' (ibid., line 330).

The content of the email was no longer discussed in the framework of the course. In the interview with Hilde, there were no indications that she was fully transparent about this topic to Mehtap. A possible reason for this could be a conflict avoidance strategy on her part.

This example shows how existing power asymmetries can be reinforced by the intervention of the Catholic students. The symbolic power of the representatives of the majority society, as set out by Bourdieu, is visible in the Muslim teacher who subjected herself to those dynamics and power structures. In the further development of this conflict, in-group and out-group dynamics became evident through the identification with one's own group and the simultaneous devaluation of the other group. Although the conflict was no longer discussed within the course, according to Klaus, the Catholic students felt that they were 'often not taken seriously by Mehtap' (ibid., lines 246f.). He deduces from this that the Catholic students consequently had difficulties of their own in taking Mehtap seriously (cf. ibid., lines 219f.).

Max sees the university part of the course as characterised by resistance in the interaction with the Muslim teacher. He feels Mehtap treats him 'like a little elementary school pupil' (IP Max, line 51). Max traces this back to her continuing to act like an elementary school teacher (cf. ibid., lines 133-143). For him, this is clearly shown in trying new methods in the role of pupils and the subsequent reflection as students. Max observes an 'underlying tension' (ibid., line 455) between Mehtap and the Catholic students since the second unit, in which the 
Catholic teacher was absent because of illness and the differences in meaning discussed above concerning the lighting of candles occurred. Here he characterises himself as 'someone who endures high tension' (ibid., line 457) and declares that the Catholic students 'had their fill of "We're elementary school pupils" (ibid., lines 438f.). Max sees the feeling of not being taken seriously as a student and the belief that the time of the course could have been spent better as reasons for this tension: 'I should still be doing that, doing that, doing that, and now I'm sitting here and letting myself be treated like my little brother' (ibid., lines 458460). What is striking from our research perspective is Max' aggressive word choice in sketching his view of the events.

\subsubsection{Consequences}

We will now discuss the consequences of the interaction dynamics of the basic practicum, starting with the perspective of the course teachers. From Mehtap's point of view, the role of the instructor is a central topic, but there was no adequate clarification of that role.

There is no tension now, but I ... have two options: Either I accept it that way, either I'm there as a guest and watch how Hilde teaches, how she deals with the students, but I purposely didn't want to be in that position and say: ... there are different methods, you can learn from each other in a group. (IP Mehtap, lines 1163-1167)

In her self-assessment, Mehtap sees herself in the role of representative, a perception that can be traced to symbolic power and power asymmetry, as has already been demonstrated several times. She has the impression that she took on an active role only when the Muslim perspective was explicitly sought or if Hilde was absent. That is why she feels she is in a subordinate, outsider position.

In a group where I am present as an outsider, take on an observer role, only made use of when it is necessary, so to speak, I can also agree with the instructor and say: 'Ok, we'll do it the way she wants.' (Ibid., lines 1788-1790)

In this context, Mehtap also comments on her further role in the basic practicum. Because of the current situation, she would not take on the role of course teacher again because she cannot identify with it: 'I do not do that. I don't do that.... I have to be able to find myself again. And that's not the case' (ibid., lines 2141-2145)

Hilde is irritated by Mehtap's lack of response to their joint planning. She describes her as 'always slightly insecure when [she] does not get any feedback 
on such a change' (IP Hilde, lines $1477 \mathrm{f}$.). As a result of their working together, Hilde concludes that difficult themes should have been addressed. In her view, there was not enough clarification of the purpose the basic practicum was intended to serve. Likewise, not enough attention was paid to the fundamental questions concerning the goals, content, and roles in the practicum (cf. ibid., lines 144-147). According to Hilde, an understanding of the opportunities or the added value of interreligious work is needed (cf. ibid., lines 2294f.). These include the following questions:

What is the role, what are the roles in the basic practicum? Whether I feel responsible for one group or [for] the whole group, somehow. (Ibid., lines 1120-1122)

It also takes time, space, and encouragement for change and joint learning (cf. ibid., lines $975 \mathrm{f}$.). Hilde holds that understanding in the form of a bilateral encounter is not expedient; rather, clarifications with the instructors of interreligious courses and with the university institutes would be necessary (cf. ibid., lines 2056, 2446-2449).

As a further consequence of leading the basic practicum, Hilde would like to take a less dominant role. At the same time, however, she believes that withdrawing from the last session would not have made Mehtap become more involved in leading the course (cf. ibid., lines 506-528). But Hilde also asks herself the fundamental question of whether she does not automatically have an intrusive effect on the Muslim group through an adopted leadership role and that this prevents the development of independent Islamic religious education (cf. ibid., lines 2496-2501). With Hilde, self-doubt and uncertainty remain: What is possible and allowed? Where are the limits? Where does one hurt others?

With respect to the students, the consequences focus on the group work within the framework of the course. From Esra's point of view, the interreligious course offers the students the chance to get to know each other and find common ground:

You also learn to see things from a different point of view. You also have a different perspective then.... And you also learn a lot ... what they think about certain things and what they think about Islam. (IP Esra, lines 229-232)

It is striking that Esra speaks here in a distancing way and refers to the Catholic students as 'they'. During the interview, Esra emphasises that the group work is an appropriate instrument for creating commonalities (cf. ibid., lines 182-197).

Elmas is also convinced that, compared to other social forms, group work makes it possible to learn together: 'The problem is that you don't talk if it's not necessary. But if we are to work together, then it fits' (IP Elmas, lines $237 \mathrm{f}$.). 
Emine emphasises in particular - in addition to the various tasks that are performed in group work - the importance of relationships: 'The relationship, that exists in the group work' (IP Emine, line 620). Basically, she assesses the interreligious character of the basic practicum as positive: 'And that is so good to be in a mixed group in the university part' (ibid., lines 599f.).

In Meltem's assessment, social forms like group work were important for the success of interreligious learning. This experience was 'super' (IP Meltem, line 152) for Meltem, and she would like to have such experiences 'on occasion' (ibid., line 153). Regarding the procedure, Meltem recommends that

the professors explain the task to them at the beginning, and then you sit down in mixed groups. Then it just takes shape perhaps - also more interpersonally - you also take a lot of the other religion with you. (IP Meltem, lines 485-489)

Meltem states that a special result of the course is that, because of her interaction with others, she was stimulated to reflect on herself, and this is accompanied by an increased interest in her own faith. So she says that she began to read the Qur'an in Turkish, 'so that I understand it' (ibid., line 1191).

For Klara, listening to each other is important. In her opinion, students should have the opportunity to explore the other religion by asking questions. A religious mixture in the learning group is a basic condition here for her (cf. IP Klara, lines 79-86).

Klaus concludes from the course that he and the other students 'want to be perceived as academic people or as students' (IP Klaus, line 286). He criticises the 'role reversal' that Mehtap had initiated. In addition, he accuses Mehtap of not being able to distinguish between reflective and methodological and practical levels (cf. ibid., lines $247 \mathrm{f}$.). As a result of this conflict, Klaus wants to bring his view of the situation 'into the evaluation' (ibid., lines $347 \mathrm{f}$.). He regrets that he did not address the conflict in the group. At the same time, however, he admits that he has chosen the - for him - more 'pleasant' method: 'and somehow I've been able to avoid addressing it personally' (ibid., lines 354-356). Moreover, it becomes clear that Klaus chooses the means of power available to him in his position (the evaluation) to resolve the conflict in the end to his own satisfaction.

Sonja, another Catholic student, views the practicum group as a place of interreligious exchange (cf. IP Sonja, line 463). She also identifies a conflict between Catholic students and the Muslim course teacher when they talked about interreligious celebrations. Sonja criticised such celebrations because of the great effort they would take and the likelihood of it being confused with a Mass. This led to a discussion between her and the Muslim course instructor 
in which several Catholic students gradually became involved. Sonja reports on this event as follows:

And then suddenly several people were standing near me and then there was this stupid situation with the others just listening and standing around like that. And then there was just a bit of a bad situation; she was facing us, and then suddenly all the Roman Catholic students were standing around us and that was a bit difficult because then she felt she was being attacked even more because we were all standing around her. (Ibid., lines 194-201)

On the one hand, Sonja sees the conversation with the Catholic students as a 'dialogue' (ibid., line 204) and at the same time talks about aspects that point to 'slander' (ibid., lines 249f.) against Mehtap. Sonja's way of expressing herself here seems ambivalent. She appears to be caught in a dilemma, and some of her statements give the impression that not everything that happened in the conflict was honest and transparent. One suspects that on the one hand there was a taboo against speaking about it - it seems they were not permitted to talk about the conflict openly. On the other hand, this may, at bottom, even involve a distinct question of power, i.e., that some strong parties are committed to ensuring that the topic is taboo and that the roles and parts played by individuals did not become obvious. This example makes it clear that one consequence of unresolved conflicts can be that students could subsequently resort to problematic strategies such as non-transparent action.

The tensions identified in this area of conflict reflect power relations, based theoretically in the 'struggle for recognition'. These constellations are to be regarded as the result of social positioning, social status, and corresponding negotiations.

\subsubsection{Preliminary Conclusion}

The team teaching and thus the question of leading the course as well as its effects on the students and the dynamics of the groups lay at the centre of the field of tension of 'process, communication, and group dynamics'. Because she felt primarily responsible for the Muslim students, the Muslim course leader also answered their inquiries regarding the course's scheduling conflict with another course and their concomitant absence. But she did so privately with the Muslim students and settled on the solution described above without discussing the problem with the entire group and with Hilde. This approach annoyed the Catholic students.

Altogether, based on our findings, it seems necessary to work together with the course instructors to develop a concept of interreligious leadership and to 
communicate it in a transparent way. Here the clarification of responsibilities is important. It also seems advisable that at least one course teacher has a permanent position at the Institute of Practical Theology or the Institute of Islamic Theology and Religious Education.

Another central area concerns the perception and processing of conflicts. The conflicts were not openly addressed by either the students or the course teachers. It is clear that, for course instructors, good interpersonal collaboration turns out to be a prerequisite for addressing and dealing with conflicts.

To be able to communicate successfully with each other in an interreligious context, the parties involved need to live with ambiguity. This entails the ability to tolerate 'disruptions' and contradictions and, if necessary, to process them. This includes the knowledge that problems and difficulties can arise. To deal with this, it is important that no blame be assigned, but that a joint attempt is made to analyse the situation, to understand the concerns, and to target possible solutions.

Joint planning with all course teachers in interreligious courses is recommended. For the further development of the course, the feedback should be obtained from the departments to promote exchange and growth. The communication of goals and tasks of the interreligious courses by the department heads is central to this process.

\subsection{Area of Conflict 3: Conflict about 'Ideal' Religious Education and Recognition}

The third area of conflict in the university setting is comprised by the different views of the participants regarding successful or 'ideal' religious education. Closely associated with this are the social recognition of one's own religion as well as the social and religious status of religious education. Accordingly, this area of conflict also affects the perception of public discourse and its effects, which form the background of the university course.

This field of conflict is directed more inward and examines - more intensively than the previous fields of tension do - what expectations do the religious communities themselves and parents have of religious education. Starting from this, in this field of conflict the two settings of school and university are linked through religious education. The belief of the religion teachers and the course instructors in their self-efficacy takes on central significance. When religion teachers or university teachers see that they are effective in their teaching and communication in the corresponding educational contexts - especially in the school setting with respect to the various representatives of the school com- 
munity (headmasters/mistresses, colleagues, pupils, parents, society), their motivation and determination to act professionally increases.

The social filters through which teachers perceive themselves or from which they have to identify with or distinguish themselves play an important role in the development of and the lack of belief in their efficacy. This means that, as in the previous chapters, social, religious, and political power and power asymmetries that contribute to the understanding of conflicts in interreligious dynamics must be taken into account.

\subsubsection{Causes and Influential Factors}

As with the other areas of tension, we turn first to the structural conditions in this area of conflict.

The course instructors display inequalities regarding religious education that can point to power asymmetries and relations of inequality on the one hand as well to general conditions on the other. These conditions often reflect social conditions - and thus equal or unequal social treatment. Mehtap reports that Islamic religion teachers have to teach at several schools to gain sufficient teaching hours to meet the obligations of their appointment. In addition, the teaching times in the afternoon prevented the Islamic religion teachers from being integrated into school life and the school community:

Our teachers teach in at least four or five different schools. And they don't feel integrated one hundred percent into this ... school; nor can they be integrated ... because they teach in the afternoons. (IP Mehtap, lines 221-223)

Mehtap sees another difference between Catholic and Islamic religious education in the group of pupils with no religious background who prefer to attend Catholic religious education. Mehtap, who also works as a religion teacher, assumes that the parents' interest in certain values being conveyed plays a role here, which they see Catholic teaching as providing:

And in Catholic religious education, as I understood from my colleague, the children with no religious background enrol in that education again because ... secular parents find it important that certain values be transmitted. (Ibid., lines 336-339)

Another circumstance that Mehtap sees as having a detrimental effect on Islamic religious education is the fact that Islamic religious teachers are exposed to greater pressure due to the concepts and ideas of parents, the religious community, and internal professional aspects. In particular, parents are a non-negligible 
influential factor in Islamic religious education. Their idea of religious education is, according to Mehtap, often oriented to religious education in mosques. This fact is decisive in whether they enrol their children in the class. The competition between mosque education and religious education at school becomes clear from Mehtap's descriptions:

At least that's how I learned that parents have a certain [understanding] of Islamic religious education. The parents have ... expectations.... An example would be memorising the suras. As a teacher, you can say ... I refuse to do that, but you will notice ... that the parents are not satisfied or they either send their children to the mosque as competition ... or ... they say ... 'I'm just taking my child out of the course.' (Ibid., lines 236-238; 255-259)

Mehtap's observations suggest that discussions and exchange about the concerns, goals, and content of contemporary religious education are not possible here. Mehtap relates that, as a religion teacher, she must 'keep up with this religious socialisation of the parents'; she also speaks, however, of the fact that parental ideas 'also ... differ from each other' insofar as 'the same understanding' (ibid., lines 476-478) of religious education does not always emerge.

These expectations by Muslim parents, who, according to Mehtap, often want religious education in the sense of religious instruction, represent great challenges for religion teachers. In this context, Mehtap draws attention to the fact that this places very high demands on the ability of Islamic religion teachers to differentiate, which also results in high demands on Mehtap as an instructor in training.

From the point of view of a teacher, they ... come from different religious backgrounds. ... Each religion teacher among us ... depending on their origin ... has a different understanding of Islam, which means that it must also have some influence on their Islamic lessons. That's the reality. (Ibid., lines 229-234)

According to Mehtap, flexibility regarding the themes in religious education is also required by the general temporal conditions of the lessons. In their opinion, time is limited, especially because of the changes in locale (classrooms or schools) the teachers need to make, which means that the implementation of a wide range of topics is hardly possible:

I have only ... 50 minutes.... Of these 50 minutes I have to count on losing 5 because I have to pick up the children, another 5 minutes because I have to bring them back, and for another 5 I need to ask if they have learned suras ... here, for two or three minutes, they have the opportunity to learn the right pronunciation. ... Time is running out for me. ... And if I still have to take into account that after the lesson ... I have to teach in another elementary school. (Ibid., lines 427-445) 
Aside from the time limitations placed on her teaching, Mehtap sees Islamic religious education as challenged by the issue of the language of education. As a particular difficulty, Mehtap mentions the problem that some Muslim students do not want to pray in German:

I also have students who say, 'Well, we don't do a dua, we don't do prayers in German. Instead of praying in German, I will recite a sura!' ... Last week ... I had a student who said: 'I will recite an Amena Rasulu.' Imagine that ... he memorised that. The student said, 'I don't want to pray in German.' (Ibid., lines 1508-1512)

Mehtap explains that children's religious language is tied to their mother tongue and that it is a particular challenge to learn the content of their faith in German.

And on top of that, the religious language 'felt' by the children is still their mother tongue ... and I can only slowly prepare them step by step so that they can also express themselves in German. (Ibid., lines 1506-1508)

Even for the students, Mehtap says, it is difficult to speak in German, since their religious language contains many metaphors that cannot be easily translated:

Yes, this metaphorical language.... Last year I also noticed that the Muslim students even had to become familiar with the language, with the religious language, with German, so to speak. They're even having trouble. (Ibid., lines 1544-1547)

Hilde's perspective complements Mehtap's impressions. She also describes the pressure on Islamic religious education, which she observes impacts Mehtap in a particular way (cf. IP Hilde, lines 927-946). In her opinion, children and young people are strictly educated or socialised by mosques and families, and therefore encounters with other conceptions or religious traditions trigger feelings of being threatened. This has a considerable influence on religious education and also has an effect on the situation of the basic practicum:

And maybe it's still the case that those who come to study now have been very socialised by the family or by the mosque communities, and for them this range is sometimes also a danger and a threat, and they lose what belongs to them then, right? (Ibid., lines 2640-2643)

According to Hilde, the challenges for Islamic religious teachers are above all to learn to deal with the pressure of mosque communities and families. Also, there is great heterogeneity in the Muslim classes, and the German language skills of many pupils are inadequate (cf. ibid., lines 914-927). What is remarkable about Hilde's statement is that she speaks in more detail about Islamic religious education than about Catholic religious education. She merely notes that, from her 
point of view, less pressure is exerted by the family and the church (cf. ibid., lines 946-950).

In principle, the example of the Islamic course instructor shows particularly clearly in this section that the school represents a network of relationships or expectations in which conflicts can arise due to the non-fulfilment of such expectations by one or more parties in the school community. From the point of view of the Islamic religion teacher and course instructor, the conflict between religious education, religion teacher, and parents is particularly striking. Religious teachers are involved in this context of expectation and cannot escape it. They cannot freely determine their teaching activities themselves but must gear them to the expectations of the individual actors of the school community. This is especially true with regard to parents. They are obviously the largest source of conflict for the Islamic religion teacher and can threaten various sanctions, including taking their children out of religious education.

\subsubsection{Behaviour and Interactions}

This section looks at the behaviour and interactions triggered by the initial conditions described above. We will start with the perspective of the course instructors.

In our comments up until now, it was stated that there are numerous constraints to which Islamic religious teachers and Islamic religious education in particular are exposed. Mehtap describes how she feels pressured by the expectations of parents and the religious community:

If I go there as an open-minded teacher and say ...: 'I am planning lessons where the children will be stimulated to think, but detached from religious content', then sooner or later I will lose my students. It's about securing my job. If I don't meet the expectations of the parents, there will be consequences. (IP Mehtap, lines 357-361)

Mehtap relates that she is reluctant to make the lessons more playful. She experiences the negative reactions of parents who want the 'classical' form of education that has existed up to now as a kind of 'control' (cf. ibid., lines 404-410; 422f.) - which also becomes visible when classes are cancelled:

So, I can only say this: I have not been able to teach on two Mondays because of these holidays. ... And I was approached by the parents about just what is going on because they have not had any religious education for two weeks. I am 90\% sure that the content I pass on to the children ... will be told to them and the parents will listen to it, they say yes, or ... they question it. (Ibid., lines 369-374) 
The interest of parents in the content of religious education that becomes visible here is not to be regarded as negative in principle. But Mehtap experiences it as a limitation. Whether the constraints described actually exist cannot be clarified beyond doubt - but it is important in this context that Mehtap subjectively perceives the reactions to her teaching in this way and that this leads to real approaches and consequences.

The above statements refer to intrareligious conflict dynamics that can be interpreted from the perspective of symbolic power. Thus, in the context of their religious communities, Islamic religion teachers find themselves in dynamics that point to 'internal' power asymmetries. Since Islamic religious education has only become established in schools in recent decades, teachers are challenged to negotiate their social status and recognition - both within and outside their religious context - and to assert themselves in the face of resistance. Honneth's concept of the 'struggle for recognition' represents a possible analytical framework for recording and interpretation of interreligious and intrareligious conflicts.

Mehtap's statements show that Islamic religious education (and in particular how parents view it) is still largely characterised by a material understanding of education that focuses on content and pays little attention to the individual pupil or the learning group. In this respect, Mehtap also sees herself as limited, compared to her Catholic colleague because of the content requirements she has to fulfil as a religion teacher. Here her image of Catholic religion teachers becomes clear, which she uses argumentatively as contrast persons: the Catholics could work much more freely with content and also include current contexts in their lessons. Mehtap thinks that, in principle, these options for action are not available to her because of the prescribed content:

And I, as an Islamic religion teacher ... I am bound to the content. I can't talk about anything I want or address anything about politics or what's in the media, I can't do that. (Ibid., lines 345-348)

It becomes apparent here that Mehtap sees no room for contemporary themes under the general conditions of Islamic religious education. She feels pressured by various circumstances and unable to prioritise others beyond the prescribed content.

When selecting strategies and behaviour for her own religious education, Mehtap often asks herself the question of how to deal with the diversity of understandings of faith without becoming arbitrary. She proposes a standardisation, which she finds in the curriculum: 
Yes, to avoid the problem that every religion teacher ... teaches whatever he or she wants ..., what he or she feels closer to, so to speak, there is the curriculum.... This has the advantage that all religion teachers, there are over 400 of us throughout Austria, have to adhere to the curriculum. (Ibid., lines 314-330)

Regarding the curriculum, Mehtap strongly emphasises its normative role and points out the great differences between the Islamic and Catholic curricula: 'and if you have looked at our curriculum ... it is very different from Catholic religious education' (ibid., lines 316f.).

From the analysis of the interview texts, it becomes clear that Mehtap has concerns about numerous aspects of the curriculum, such as a possible lack of standardisation, too much relativisation, or too much openness. Against this background, she possibly sets limits for herself as to what she can do and say, which in turn makes it difficult for her. Again and again, Mehtap emphasises that the Catholic curriculum grants more latitude to teachers and religious education as a whole compared to the Islamic curriculum. She emphasises that the Catholic curriculum is 'detached from ... any content'; there are 'only these ten competences left' which represent 'freedom for the teacher' (ibid., lines 331336). The freedom that, from Mehtap's point of view, characterises Catholic religious education tends to be problematic for her, since it also includes wilfulness and arbitrariness. She says that much of the Catholic approach to teaching is left to the individual teacher. At the same time, however, her statements show that she wants more freedom for herself in religious education.

The Catholic course instructor Hilde advocates a contrary opinion in this context. She refuses to adhere to teaching principles that are too strict. Instead, she argues for a more creative, informal approach to content and methods than Mehtap. She bases her stance on a theological statement: she places the notion of the loving gaze at the centre and thinks that one can 'trust that this God looks lovingly at us and that we ourselves look lovingly at ourselves' (IP Hilde, lines $2650 \mathrm{f}$.).

Basically, the views of the teachers differ in that Mehtap is more strongly influenced by a didactic concept based on specifications and reproduction and focuses on the question of concrete methods and instructions for action. This entails a controlling approach. Hilde, on the other hand, raises thematic and methodological possibilities and leaves it to the students to choose independently among them and to develop their own teaching style.

Compared to Mehtap, Hilde hardly comments on the challenges of Catholic religious education. She describes her view of the role of religion teachers in general, using the metaphor of a package: 
I get a package ... from my religious community.... That's the content, that's my package. I take the package, open the package, look inside, peruse it, and ... also with a view to the students: What can they use from the package? - ... I try to work with it. (Ibid., lines 986-990)

Hilde sees Mehtap's role and attitude as follows:

I get a package, I take the package and pass that package on to the students. (Ibid., lines 984f.)

Hilde refers implicitly here to an instructionalist teaching and learning paradigm in which the teacher controls the learning process. The teacher is active, and the students are passive recipients of the content or subject matter to be learned. In this paradigm, learning is a 'one-way street' from the teacher to the student. Hilde's metaphor of the package illustrates that in such an understanding of learning, the students have no opportunity to participate or be involved in the formation of the content since it is pre-structured according to what the teachers or the religious community wants. According to Hilde, the instructionalist teaching and learning paradigm that she observes in Mehtap not only concerns religious education in school but is also reflected in the focal points that her colleague places in the accompanying university course. Thus, Mehtap sees it as her task to protect the students from hostility and from 'interference by the mosque communities and the parents from these different currents and cultures' (ibid., lines 935f.) by providing them with 'a specific procedure' (ibid., line 937) and giving them clear instructions. The description contains echoes of 'master-apprentice didactics', in which the apprentice follows the instructions of the master but does not develop his own professional qualities.

Power asymmetries and the resulting insecurity felt by Islamic religion teachers are clearly perceived by the course instructors: Hilde describes it as a 'huge shortcoming' (ibid., line 2067) that the practicum only takes place in Catholic religious education. She would like to see the Islamic religion teachers show more courage in opening up their religion classes with the attitude: 'This is how it is in our case, and this should be examined and then you can develop something from it' (ibid., line 2169).

The students display different perspectives on Islamic or Catholic religious education and on the connection with the basic practicum. These perspectives focus on the social recognition of their own religion as well as on ideas of religious education. Although the Muslim student Esra criticises the orientation of the basic practicum to Catholic religious education, she does emphasise the possibility of comparison, which she sees as an opportunity for dealing with other perspectives (cf. IP Esra, lines 291f.). She enumerates the various dimensions, 
requirements, and methods of religious education that, in the case of Islamic religious education, for example, relate to content ('meanings') in particular:

If someone can do it, good, but the [Catholics] don't have any suras, verses, meanings, they don't have to do any of that. But, with us it's like this: a lot of importance is put in the school part on the fact that the students learn this with meaning. If you can convey this interreligiously in a proper way, then why not. ... But I believe that it is then somehow ... not necessary for the others, for the Catholics. (Ibid., lines 343-355)

These insights into Catholic religious education in the basic practicum mean that Esra perceives great differences between the intrareligious Islamic specialised practicum and Catholic teaching:

Now during the specialised practicum, you can see that they are actually completely different worlds. The two religion classes themselves, but they are already different worlds. ... So they do it all playfully, you can't say that - but still differently. And for us, it's more about the information; to get the information across well. That's why it was a bit different. (Ibid., lines 105-108)

The different approaches to religious education, to faith, possibly also to revelation can be illustrated by the example of Esra. In her interpretation of Islamic religious education, the focus is on the transmission of information, i.e., content. Esra cannot clearly define the approach in Catholic religious education, but she does notice the playful element.

Elmas, another Muslim student, also believes that the two approaches are different. For her, the goal of a successful teacher education programme is to learn how to make children think:

But I just noticed, not only through these lessons - we have now had the basic university part. We have didactics, we also have a specialised practicum with Mehtap and because of that I can just say: 'We learn how to make the children think.' And if you can really do that, then it's a success, I think. (IP Elmas, lines 555-559)

With regard to the perception of Islamic religious education, Elmas reflects on her own religious socialisation and stresses the one-sided emphasis on learning content: 'We only learned, learned, learned content' (ibid., lines 665f.).

Elmas expresses concerns about the interfaith components of the basic practicum. For her, this raises the question of why she should learn methods from Catholic religious education at all (cf. ibid., lines 222f., $410 \mathrm{f}$.). In this context, she makes an argument similar to the one made by Mehtap. Keeping the parents in mind, she does not think that they can just take over everything from Catholic religious education: 
There is also pressure from the parents ... because if you don't learn anything from the class on Islam and go home, and the children, let's say, did nothing but paint, that doesn't go down well. (Ibid., lines 487-490)

Nevertheless, she is fascinated by the calm character of Catholic religious education: 'There's no hurry; it's not hectic, and I've never done that before' (ibid., lines $590 \mathrm{f}$.).

The student Emine observes other differences between the different forms of religious education. She pins down the differences between Catholic and Islamic curriculum in the focus on competence and goals:

For example, that the students can also think for themselves after the classes, and if there is a problem, they can solve it. That they learned in class. ... But our curriculum doesn't quite have that; it just says, for example, 'Pupils should be able to do this and be able to do this.' (IP Emine, lines 585-595)

Emine also wants to encourage pupils and teachers to visit the places where religion is lived, i.e., mosques, within the framework of Islamic religious education. ${ }^{8}$

Meltem, another Muslim student, attaches great importance to 'motivation' (IP Meltem, line 893) for successful religious education. She repeats several times the importance of the motivation she perceives in the feedback of interested children and illustrates this with examples. For example, she heard a child ask: 'Can we do another lesson in religion?' (ibid., line 942). These are things that motivate Meltem as a religion teacher.

In addition to motivation, being qualified in her own Islamic theology also plays a central role for Meltem. But insights into Christian theology are also of great importance in her basic understanding of herself as a religion teacher: 'If you want to be a religion teacher, then you have to be able to compare religions' (ibid., line 639).

The Muslim course instructor (Mehtap) and the students have similar views of the university course. All of them focused more on teaching methods and less on didactic questions. The student Emine, for example, is satisfied with the 'information ... on how to design lessons' (IP Emine, line 129).

This orientation is also very popular with Catholic students. For example, Max 'even perceived the [teaching] event as a tool event' (IP Max, lines 532f.). At the centre of the course, there was the will to help the students

8 See the remarks in area of conflict 'identity and confessionality' in the school setting (chapter 4.4). 
reflect on our path as teachers, that we do not get upset about things that have nothing to do with it now because these theological disputes are of relatively little use to us in school. (Ibid., lines 537-540)

For Max, school is not an appropriate place for theological disputes. His concept of religious education is similar to Mehtap's. For both, methods are particularly important for bringing religion-related content closer to pupils in religious education.

Klaus also wanted to learn from this course how to deal with religious content and topics in the classroom on a 'practical, exemplary level' (IP Klaus, line 249): 'I have a toolbox like that and I was able to throw a little something into it again' (ibid., lines 371-374).

There are differences, however, in their views of religious education as to which methods are appropriate or inappropriate for the respective religion. Mehtap's desire to focus on methodological questions in the basic practicum - as the previous examples show - is more oriented towards the Muslim students. This is also advocated and appreciated by them. For this reason, however, some Catholic students criticise Mehtap's communication style: she focused on conveying to the students what had been predetermined and planned but did not enter into a critical self-reflexive dialogue with them, even when she spoke about Catholic beliefs or rituals as a Muslim course teacher (cf. ibid., lines 193-220). This approach, which could well be interpreted as a more instructionalist approach to religious education, led to tensions with Catholic students (see chapter 5.3).

In turn, in looking back on the course, the Catholic student Klara emphasises - in contrast to her fellow students Max, Klaus, and Sonja -the focal points that correspond to Hilde's idea of ideal religious education. Although she generally welcomes both 'practical relevance' and 'tools' (IP Klara, lines 105-110), which she learned in the course and which she can apply in concrete lessons, in her opinion interreligious learning is primarily a feature of high-quality religious education:

Well, just the fact that I can take a position or form an opinion for myself personally about interreligious dialogue, about Islam perhaps, in exchange with people from that religion, this of course also enriches my lessons because I can then also convey this approach perhaps, which I have discovered to be right for myself. (Ibid., lines 346-352)

Klara therefore describes a type of learning that goes 'beyond the actual learning in the course' (ibid., lines 331f.). Particularly important here is the opportunity to develop one's own view in exchange with people from other religions. Consequently, she represents a concept of religious education that does not convey strict content or truths but rather initiates a personal examination of religion-re- 
lated content - even outside the school context. As for Hilde, there is ' $a$ different kind of learning' (ibid., lines 335f.) at the centre for her, which takes place in contact and togetherness.

In general, it becomes clear from this section that religion is a central building block of identity. Elements emerge that point to the theoretical construction of a 'fictitious imaginary we' in which the dynamics of stabilisation inwards and demarcation outwards from the religious 'other' are manifested. This entails considerable conflict potential for interreligious educational processes.

\subsubsection{Consequences}

Points of view that refer to social power asymmetries become visible here as consequences. Theoretically, these refer to the concept of Honneth's 'struggle for recognition' as well as the established-outsider theory described by Scotson and Elias.

The course teacher Mehtap mentions the German language as a challenge in Islamic religious education. She also always has to do extra preliminary work so that communication is possible. This also applies to the students, who are responsible for 'successful' communication during the practicum and have to cope with the problems the majority society has with Muslims. Mehtap cites the headscarf as an example from her own private sphere and describes the challenges and inconveniences that she associates with it as a Muslim woman. She emphasises how often she is asked about the headscarf in the university course and elsewhere.

I know what I struggle with as a Muslim woman with a headscarf. I am always confronted with prejudices.... I have to overcome these hurdles ... so that normal communication between me and my interlocutors is at all possible.... I have always dealt with this hurdle in advance. (IP Mehtap, lines 756-759)

Mehtap also observes this problem among Muslim female students. She tells of a student who could not achieve her career aspirations because of her headscarf:

Some lack theological knowledge because they are forced by society to do this study now. I know a woman from last year who contacted me three to four years ago and asked me ... if I could help her because she absolutely wants to be an architect. Then I said: 'Is it so difficult for you to find a job now?' And she told me her problems because of the headscarf, and she started to study Islamic religious education with us last year. (Ibid., lines 926-931) 
Mehtap also makes it clear that Catholic and Muslim students have different reasons for studying religion (cf. ibid., lines 935f.).

Hilde feels that Mehtap's approach and desires concerning content are strongly influenced by the social situation of Muslims. She describes 'Mehtap's desire ... to pass on a lot of methodical and didactic knowledge' (IP Hilde, lines $154 \mathrm{f}$.) and attributes this to Mehtap's concern about an unreflective transfer of Catholic didactic and theological culture to Muslim students. Hilde believes that Mehtap fears that Muslim students will adopt Catholic methods without reflecting on them because they seem to be good or appealing (cf. ibid., lines 185188, 319-322). Hilde is disturbed by Mehtap's concepts and wonders if she is too dominant with her own approach. Hilde resolves this dilemma during the interview by articulating her annoyance and holds Muslim religious educators responsible: 'Damn, that's your job, to see for yourself what you have to do. And why are you taking up an image that may not be yours?' (ibid., lines 2531f.).

Hilde seems to have fallen into a 'double-bind' situation in her role: she cannot give up her own convictions and at the same time her own convictions are not compatible with the attitude of Mehtap and some Muslim students. So, she reflects on this and looks for solutions. Eventually, the only possibility she sees is that of not becoming a course teacher in the next academic year:

I think, Hilde, you have to get out of the project because what you're doing isn't doing any good for the students, it isn't doing any good for the Muslim students. There is something that goes against much of what they experience and think in their socialisation, in their culture, or then just how they experience religion ... and think. (Ibid., lines 2733-2740)

The consequences for the students can be summarised as follows: the Muslim students are very much taken up with the question of whether to follow Islamic or Catholic methods. This differentiation is characteristic of their point of view and has far-reaching effects on their assessment of the basic practicum. It becomes clear that there are major differences in the view of the Muslim course teacher and the students on the methodology and didactics of Catholic religious education. As an example, we can cite the example of Esra. Esra thinks that the basic practicum should take place in Islamic religious education since she cannot implement the methods learned:

But you still have pictures of Catholic, of Christian, things. You have candles in the seminar and, yes, we don't really have that. And I can't put a candle in the middle of an Islamic religious class and light it; yes, hallelujah, I can't do it. (IP Esra, lines 164-171)

As another consequence for religious education, it becomes clear that Esra, who has a more substantive understanding of religious education, attributes less con- 
tent-related learning to Catholic religious education (cf. ibid., lines 346-348). In addition, she also recognises great differences from the Christian religion. She illustrates this by the example of the Jesus story:

Isa, alihi salam, for example. We have a different view of him, and they have a completely different one. So, they have a very, very different story.... It is - yes, what I think everyone has done now - it's good that you hear it once. But from the Islamic point of view, it doesn't do much good, I think. (Ibid., lines 277-288)

Emine, on the other hand, sees fewer problems in adopting methods from Catholic religious education for Islamic education (cf. IP Emine lines 101, 534-539).

Meltem questions the concept of religious education in school; in her view, it is 'boring' (IP Meltem, line 899). She is convinced that interreligious collaboration at the university and in schools must continue. She considers the fact that 'Muslim students teach Christian, i.e., Catholic, children or vice versa' (ibid., lines 218-220) important and underscores this approach: 'In any case, this must happen' (ibid., line 220). Meltem would like to see not only a continuation of the project but an expansion of it in which in future Catholic students attend Islamic religious education.

\subsubsection{Preliminary Conclusion}

Power and power asymmetries are also evident in the third area of conflict, in which the social recognition of one's own religion and religious education as well as the struggle for an 'ideal' religious education are central. The Muslim respondents especially observe the current discussions on this and address them. Dynamics that point to established-outsider constellations also become visible.

The course teachers' statements on Catholic or Islamic religious education reflect the societal context of the Christian/Islamic religion or Islamic/Catholic religious education. Hilde hardly brings up the challenges of her own religion or Catholic religious education - especially in relation to the attitudes of parents. Mehtap, on the other hand, faces many difficulties and challenges. From her point of view, she constantly needs to explain herself, feels pressured by the parents above all and points out her relationship of dependence (the possibility of parents withdrawing their children from the class). She also feels concrete pressure from the religious community. Whether these implicit or explicit requirements are based on an actual background or whether they influence Mehtap's approach and guide her actions in the sense of self-fulfilling prophecies is not clear from the interviews. 
Regarding the acceptance of religion and religious education, Hilde describes Mehtap's problems but hardly talks about her own difficulties and challenges, either in Catholic religious education or in the Catholic religious community. Nor does she describe feeling pressured by parents. The reasons why she does not talk about this are not easy to discern. They can stem from the constitution of the majority society as well as from the lesser importance that the majority society places on religion. Last but not least, Hilde's self-image and her belief in her self-efficacy can also play an important part in this question.

The different ideas of what constitutes 'ideal' religious education have a great impact on the area of conflict. Here, the didactics and ideas about content differ widely between the two course teachers. For Mehtap, content and methods are central; for Hilde, it is sensitivity to context and interaction. But the two teachers also have fundamentally different views about what one should or should not do in religious education. Reading between the lines, one can detect a fear repeatedly expressed by Mehtap of an inadmissible mixing of Islamic religious education with Catholic. She finds it important to maintain the boundaries. For Hilde, these boundaries do not exist with respect to didactics. But she feels very unsettled by Mehtap's approaches, and this makes interreligious encounters and team teaching more difficult for her. 
